\title{
Otomotiv Sanayinde Hücresel Üretim Sisteminde Sac Parça Üretim Periyoduna Etki Eden Faktörler ve Üretim Zamanı Modellemesi
}

\author{
Yücel Can ${ }^{1 *}$ \\ 1* Oyak Renault Ar-Ge Merkezi, Bursa, Türkiye, (ORCID: 0000-0003-2086-2129), yucel.can@renault.com
}

(İlk Geliş Tarihi 29 Ekim 2020 ve Kabul Tarihi 12 Ocak 2021)

(DOI: 10.31590 /ejosat.818089)

ATIF/REFERENCE: Can, Y. (2021). Otomotiv Sanayinde Hücresel Üretim Sisteminde Sac Parça Üretim Periyoduna Etki Eden Faktörler ve Üretim Zamanı Modellemesi. Avrupa Bilim ve Teknoloji Dergisi, (21), 247-260.

$\ddot{O} \mathbf{z}$

Bu çalışmada Oyak Renault otomotiv firmasında sac parça üreten pres atölyesinde hücresel üretim modellemesi ve buna bağlı olarak optimum çevrim periyodu analizleri yapılmıştır. Pres hattının üretim hücresi kabul edildiği bu çalışmada, toplam üretim zamanına etki eden faktörler incelenmiş ve üretim kriterlerini dikkate alan bir analitik model geliştirilmiştir. Çalışma neticesinde, çevrim periyoduna bağlı faktörlerden kalıp değişim, taşıma kabı yatırım, ürün stok alanı, hammadde, ayar parça ıskarta, üretim işçilik ve üretim hızına erişim maliyetleri toplam üretim maliyetini oluşturmaktadır. Modelleme, analiz ve toplanan verilerin işlenmesi sonucunda Toplam Çevrim periyoduna tesir eden en önemli faktörün kalıp değişim süresi, parça ıskarta miktarı, ham madde ve mamul stokları ile taşıma kabı yatırım maliyeti olduğu belirlenmiştir. Kalıp değişim zamanlarının toplam zamana oranının 2. dereceden polinom fonksiyonu şeklinde azaldığı, stok alanları ve taşıma kabı yatırım maliyetinin ise lineer olarak arttığı görülmüştür. Yapılan bu çalışmada yordamsal yaklaşımla 10 gün olarak uygulanan çevrim periyodu, çalışma sonrasında \%40 azalarak optimum 6 gün olarak hesaplanmıştır.

\section{Factors Affecting Sheet Metal Production with Cellular Production System and Manufacturing Time Modeling in Automotive Industry}

\begin{abstract}
In this study, the stamping process and cycle times were analyzed in a stamping workshop that produces sheet metal parts in an automotive company. In this study that each press line has been considered as a production cell, factors affecting the production time were investigated and an analytical model has been developed that takes production criteria into account. As a result of the study, the factors about cycle period constitute the total production cost. These factors can be summarized as costs of product storage area, raw material, reject parts, production labor, reach the production speed and die change. As a result of the Cellular Production modeling, analysis and processing of the obtained data, it has been determined that the most important factors affecting the Total Cycle period is the die change time, the amount of reject parts, raw material, product storage and product container investment cost. It was observed that the ratio of die change times to total time decreased as a quadratic polynomial function, while the storage areas and product container investment cost increased linearly. In this study, the cycle period applied as 10 days with the procedural approach decreased to $40 \%$ after the study and was calculated to be 6 days as the optimum period.
\end{abstract}

Keywords: Open Time, Total Time, Production Period, Cellular Production System, Production Time Modelling, Die Change Time, Parts Container, Stockage Surface, Row Material, Sheet Metal Stock, Cost

*Sorumlu Yazar: yucel.can@renault.com 


\section{Giriş}

Üretim, "Yeni bir fiziksel varlık veya hizmet ile sonuçlanan, bir fayda meydana getirmek amacı ile yapilan faaliyetlerin bütünü" şeklinde tanımlanmaktadır. Fiziksel anlamda bir fayda meydana getirmek için yapılan çalışmalar yerine konuyu fiziksel üretim kavramıyla özelleştirmek yerinde olacaktır. Üretim sistemlerinin sinıflandırılması, sosyal-ekonomik kavramları sınıflandırma zorluğu nedeni ile sadece bir saptama olarak tanıtım niteliğinden öte gidemez. Bu nedenle üretim sistemleri, üretim yöntemlerine göre birincil üretim (hammadde üretimi), Analitik üretim (hammadde analizi), Sentetik Üretim (hammadde sentezi), Fabrikasyon Üretimi (şekil verme), Montaj Üretimi (bir araya getirmek) şeklinde tanımlanabilir. Ürün cinslerine göre sınıflandırma yaparak da üretim sınıflandırılabilir. Bunlar; demirçelik üretimi, elektriksel teçhizat üretimi, elektronik mamul üretimi şeklindedir. Üretim miktar veya akışına göre bir sınıflandırma yapmak da önemlidir. Bunlar, siparişe göre üretim (miktarı sınırlı, spesifik mamul), parti üretimi (partiler halinde) ve sürekli üretim (çeşit yok, miktar yüksek) olan kitle ve akış üretimidir $[1,2]$.

Yukarıda açıklaması yapılan parti üretimi ve sürekli üretim için daha belirleyici olmak üzere, kesikli üretim ve sürekli üretim tipleri demek daha doğru olacaktır. Üretim sistemlerinin bu kapsamı, fiziksel üretimi teşkil eden ürünün, çeşitli şekillerde üretimini gündeme getirmektedir. Fabrika veya atölye tabir edilen üretimin yapıldığı yerin yerleşimine göre de bu sınıflamayı yapmak mümkündür. Bir fabrika ya da atölyede üretim yapan araçlar (tezgâhlar, makineler vb.) çeşitli konumlarda bulunabilir. Eğer tezgâhlar belli bir sürece göre yerleşmiş ise aynı amaçlı tezgâh veya makineler aynı bölümde yerleşerek süreci gerçekleştirilir. Bu, geleneksel üretim sistemi içerisinde yer alan, çok kullanılan bir üretim sistemidir. Pahalı bir üretim sistemi olan sürece göre üretim, aynı tür tezgâhları aynı alanda kullanarak âtıl kapasite oluşturabilir. Genellikle siparişe göre üretim, miktarları az parti üretimi için kullanılır. Geleneksel üretim sistemi olan bu sistemin âtıl kapasite yaratılması gibi sakıncaları vardır.

Üretilen mamulün miktarı ile üretim faaliyetlerinin fabrika içindeki hareketi arasında yakın bir ilişki vardır. Aynı cinsten bir mamulün az veya çok sayıda üretilmesi; kullanılan makinelerin tiplerini, imalat yöntemlerini, standartları, insan gücünden yararlanma biçimini, fabrikanın yerleşim düzenini, üretim planlama ve kontrol yöntemlerini etkiler. Bütün bunlar hammaddenin mamul hale gelinceye kadar izlediği yolu, yani akışı da belirler [3]. Bu tip üretim sistemlerinde belirli bir siparişi ya da sürekli bir üretimi karşılamak için benzer veya aynı cinsten ürünler kafileler halinde diğer ürün kafilelerinin üretiminin tamamlanmasını takip eder. Atölye tipi üretimde olduğu gibi, yardımcı aletlerin ve iş metotlarının geliştirilmesi, kafilenin büyüklüğüne bağlıdır [4]. Eğer kafile bir defaya mahsus olmak üzere üretilecekse, üretimin etkinliğini arttırıcı araştırma ve geliştirme çalışmalarının maliyeti karşılanamayabilir. Kafile tipi üretimde, üretim planlama ve kontrolü atölye tipi üretime nispeten daha kolaydır. Bununla beraber, aşağıdaki durumlara göre kafile tipi üretimin kendi içinde üretim planlama ve kontrolü zorlaşabilir veya kolaylaşabilir: a) Kafilenin bir defaya mahsus olmak üzere üretilmesi b) Kafilenin düzensiz aralıklarla ihtiyaç olduğu zaman üretilmesi c) Kafilenin sürekli talebi karşılamak için bilinen zaman aralıklarında üretilmesi.

Kitle tipi üretimde kafile büyüklüğü ve ürün kafilelerinin tekrarı arttıkça, üretim planlama ve kontrol sistemi geliştirme ve uygulama faaliyetleri kolaylaşır [5]. Kafile büyüklükleri ve kafile tekrarları arttıkça, kazanılan deneyim, üretimin planlaması, planın uygulanması ve kontrolündeki en önemli zorluklardan biri olan belirsizliği azaltır. Pres, döküm, torna gibi tezgâh işlerinde, çeşitli cam ve kimyasal ürünlerin üretiminde çok rastlanılan kafile tipi üretim, endüstrinin çok yaygın bir üretim tipidir.

Günümüzün yüksek rekabet koşulları altındaki üretim ortamı, daha etkili üretim sistemleri geliştirilmesi için yoğun olarak bilimsel çalışmalar yapılmasını zorunlu kılmaktadır. $\mathrm{Bu}$ sistemler arasında hücresel üretim yöntemi sayılabilir. Hücresel üretim yöntemi diğer üretim yöntemlerinin getirdiği temel problemleri ortadan kaldırması ve yüksek verimlilik getirmesi nedeniyle tercih edilmektedir. Hücresel üretim temel olarak aynı parça ailelerinin tanımlanmasını ve ilgili üretim makinelerinin bir araya getirilmesiyle oluşturulan hücreleri kapsamaktadır [6, 7]. Makine hücre yapısı, makine-parça matrisi ile organize edilmektedir. Makine-parça matrisi makine hücresi algoritmalarının yapılandırılmasında girdi olarak kullanılmaktadır. Böylece makine-parça gruplarını tanımlayarak hücresel üretim sisteminin geliştirilmesine imkân oluşturulur [8]. Makine hücrelerinin oluşturulmasında birçok yöntem mevcuttur. Bunların arasında çok sayıda makine-parça gruplandırma algoritması sayılabilir. Örneğin, yapılan bu çalışmada makine hücrelerine parça ataması oluşturulan benzerlik matrisi ile (Çizelge 3 ve çizelge 4) düzenlenebilir.

Hücresel üretim yöntemi kullanıldığında gruplandırma mantığı ile hareket edildiği için bir parçanın üretim süresi kısalmakta ve üretim sayıları artmaktadır. Başka bir ifadeyle üretim verimliliği yükselmektedir. Bunun bir sonucu olarak da süreç içerisinde tutulması gereken stok miktarı düşmektedir [7, 9]. Hücresel üretimin bazı dezavantajları olduğu bilinmektedir. $\mathrm{Bu}$ dezavantajların başında rotalama esnekliği, talep değişkenliği, kapasite kullanımı gelmektedir [8]. Özellikle standart olmayan ürünlerin üretiminde bu dezavantajlar ortaya çıkmaktadır. Ancak bu çalışma konusu olan sac parça üretiminde kullanılan ana makineler preslerdir. Bu preslerin bir akış mantığı ile hücresel bir yapıda yerleştirilmesiyle hatlar oluşturulmaktadır. Pres makinelerinin büyük boyutlu ve yerleşim bölgesinde istenen özel alt yap1 nedeniyle, yerlerinin değiştirilmesi gibi bir durum söz konusu kolay kolay olmamaktadır. Tüm bunlardan dolayı, hücresel üretim sisteminin dezavantajlarının sac parça üretim prosesi için geçerli olmayacağı görülmüştür [10]. Bu şekilde benzer parçaların ve makinelerin gruplandırılarak üretildiği bir sistem kurulmuş olması nedeniyle, çok hızlı bir şekilde deneyim kazanılmakta, malzeme taşıma mesafeleri kısalmakta, taşınan üretim yığın miktarı azalmakta, ürün değiştirme süreleri düşmekte, akış dengelenmekte ve üretim kontrolü basitleştirilmektedir [11]. Kazanılan bu avantajlar ile üretim çevrim periyodunun ürüne ve işletmeye bağlı olarak \%40-\%90 arasında azaldığı görülmüştür. Ayrıca ürün kalitesinin de \%31 oranında iyileştiği tespit edilmiştir [12].

Hücresel üretime geçişte karşılaşılan güçlüklerin başında makinelerin konumlarının daha önceden belirlenmiş olması, ilave personel eğitim ihtiyaçları, idari ve mali sınırlamalar, atölye üretim planlaması güçlügüu, değişime karşı direnç ve devam eden yüksek yoğunlukta makine kullanımı gelmektedir. Bu konulara dönük araştırmalar devam etmektedir ancak bu güçlükler derecelendirme ve analitik modellerin içerisine dahil edilmesindeki zorluklar nedeniyle hariç tutulmaktadır [11].

$\mathrm{Bu}$ çalışmada Oyak Renault otomotiv firmasında sac parça üretimi yapan pres atölyesinde hücresel üretim yöntemi ile üretim çevrim periyodu modellemesi gerçekleştirilmiştir. Üretim 
zamanına etki eden faktörler incelenmiş ve sınıflandırılmıştır. Yapılan modelleme çalışmasında analitik bir yaklaşım kullanılmış ve modellemenin sonuçları irdelenmiştir.

\section{Materyal ve Metot}

Bu çalışmada, Oyak Renault otomotiv fabrikasında analizin yapıldığ 1 zaman aralığında üretilmekte olan 4 tip araba üretimi izlenmiştir. TİP A arabasından 100 adet/gün, TİP B arabasından 90 adet/gün, TİP $\mathrm{C}$ arabasından 125 adet/gün ve TİP D arabasından da 100 adet/gün üretim olmak üzere toplam 415 adet/gün araba için üretilen toplam 163 referans parça üzerinden pres hatlarındaki üretim analizi gerçekleştirilmiştir.

Söz konusu arabaların sac parçaları, arabanın dış görünümünü oluşturan yüzey parçaları (ön kaput, arka kaput, tavan ve kapı dış sacları), iç yüzey parçalarından (ön kaput astarı, arka kaput astarı, kapı astarı ya da şasiyi oluşturan parçalar) oluşmaktadır. Üretilen parçaların geometrilerine bağlı olarak farklı işlem adımlarının ardışık uygulanmasıyla sac levhadan üretilmektedir. $\mathrm{Bu}$ işlemler parçanın geometrisine ve kalıp konstrüksiyonuna göre değişmekle birlikte, bir parçanın üretiminde gerçekleştirilen operasyonlar, genel olarak açınım kesme, derin çekme /form verme, ütüleme, çevre kesme, kenar kıvırma, boşaltma / delik delme işlemlerinden oluşmaktadır. Şekil 1 'de işlemler uygulama sırasına bağlı olarak gösterilmektedir.

Plastik şekillendirme işleminde genel olarak kullanılan sac kaliteleri, parçanın kullanıldığı yere ve parçadan beklenen özelliğe göre (D1ş yüzey görünümü, mukavemet) çeşitlilik göstermektedir. Yüzey durumuna göre, dış yüzey ya da iç yüzey sacları şeklinde iki türdür. Çekme dayanımına göre alaşımsız saclar, ekstra derin çekme (140-160 N/mm²), derin çekme (160$220 \mathrm{~N} / \mathrm{mm}^{2}$ ) ve ticari kalite saclar şeklinde tanımlanmaktadır. Çekme dayanımına göre alaşımlı saclar; Yüksek mukavemetli (360-450 N/mm²) ve Çok yüksek mukavemetli (750-100-1500 $\mathrm{N} / \mathrm{mm}^{2}$ ) saclar olarak sınıflandırılmaktadır. Parçanın özelliği ve parçadan beklenen şartlara göre, mühendislik servisi tarafından standardize edilmiş sac kaliteleri tanımlanmaktadır. Üretimde her bir parça için standart olarak belirlenmiş sac kalite ve ebatları kullanılmaktadir.
Presleme üretimi; pres kalıplarının ardışık olarak hat şeklinde konumlandırılmış olarak preslere montaj edilerek yapılmaktadır. Üretim akışı, parçanın tasarımına bağlı olarak, Şekil 1'de gibi levha sac, makas, açınım kesme ya da direkt form verme işlemi uygulanan parçalar olarak 3 ayrı şekilde gruplandırılabilir. Ölçümlerin yapıldığı pres atölyesi 5 pres hattından oluşmaktadır. Teknik özelliklerine göre gruplandırılmış 5 hattan oluşan Pres Atölyesi yerleşim planı Şekil 2'de gösterilmiştir. Üretimi yapılan parçalar üretilmekte olan araba tiplerinden bağımsız olarak parça teknik özelliklerine göre aşağıda değinilen benzerlik matrisi kriterlerine göre hatlara parça ataması yapılmaktadır. Şekil 3'te çalışmanın yapıldığı pres atölyesi ve üretilen arabaların (otomobillerin) sac parçalarından örnekler sunulmuştur. Yapılan çalışma; 1- Parçaların hücrelere atanması 2 - Çevrim periyodu optimizasyonu olarak iki ana başlıkta değerlendirilmiştir.

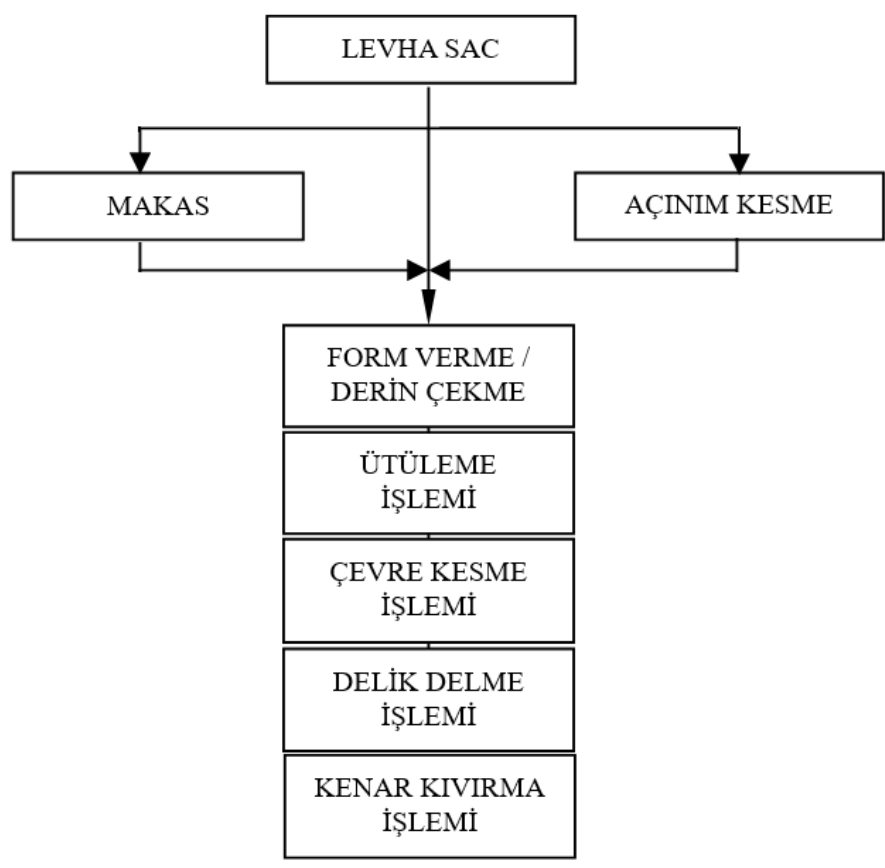

Şekil 1. Genel Olarak Presleme Üretim Prosesi Akış Şeması 


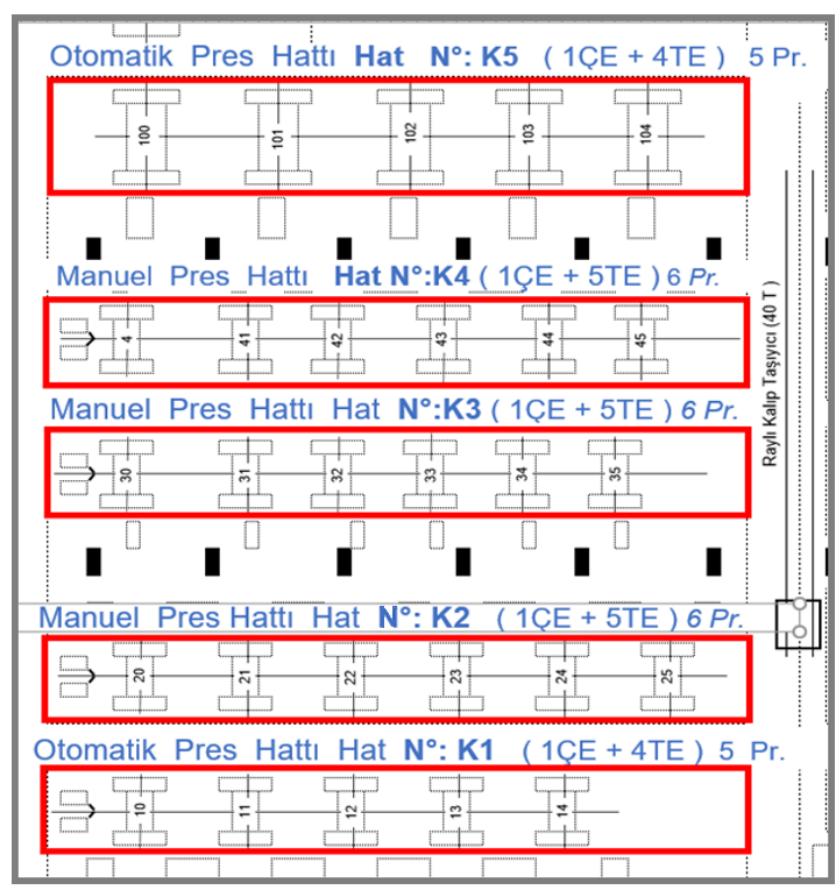

Şekil 2. Ölçümlerin Yapıldı̆̆ı Pres Atölyesi Pres Hatları Yerleşim Planı (ÇE: Çift Etkili Pres, TE: Tek Etkili Pres)
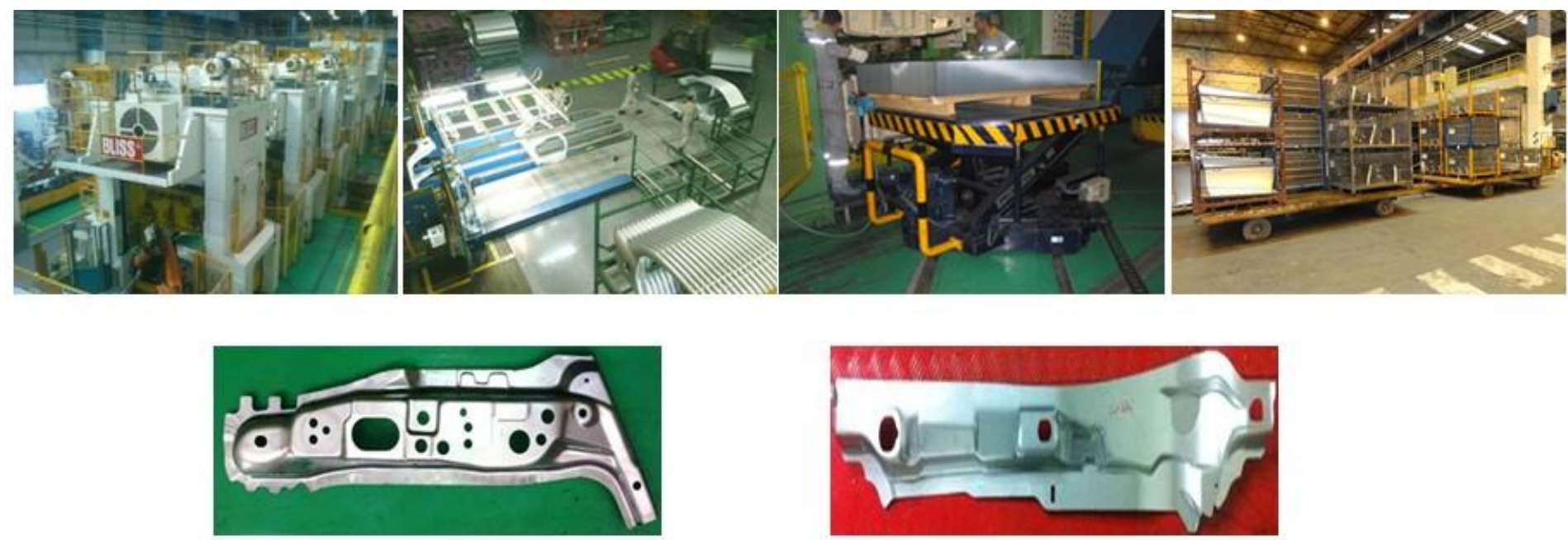

Şekil 3. Ölçümlerin Yapıldı̆̆ı Pres Atölyesinden ve Üretilen Parçalardan Örnek Görüntüler: a) Pres Hattı, b) Parça Çıkış Bölgesi ve Stoklama Bölgesi, c) Pres Kalıbı d) Taşıma Kapları e) Üretilen Sac Parçalar

\subsection{Hücrelere Parça Atanması}

Hücrelere parça atama işlemi için tasarlanan Excel programının, işlem adımları aşağıdaki şekilde oluşturulmuştur.

Üretim çevrim periyodu modelleme çalışması kapsamında ölçümlerin yapıldığı pres atölyesinde, pres hattı (Şekil 3a), pres hat sonu üretilmiş parça çıkış bölgesi ve pres hat sonunda taşıma kaplarına parça dizme (stoklama) bölgesi (Şekil 3b), manuel pres hattı masasına yüklenmiş sac paket ve hat başı presine montajı yapılmış pres kalıbı (Şekil 3c), üretilmiş parçaların stoklanmasını ve ambara sevk edilmesini sağlayan taşıma kapları (Şekil 3d) ve pres hattında üretilen örnek sac parçaları (Şekil 3e) fotoğrafları şekil 3 'te verilmiştir.

\section{Adım 1: Sabit değerlerin girilmesi (parça birim üretim süreleri ve ortalama direkt \& endirekt kayıların girilmesi)}

Standart parça birim üretim süreleri zaman ölçümü ile belirlenmektedir. Diğer kayıplar, her bir makine ve hücre grubu için üretim kayıtlarından alınmıştır. Bu kayıtlar, Oyak Renault üretim sistemini izlemek üzere oluşturulmuş SMP99 (Renault Üretim İzleme Sistemi) adı verilen bir bilgisayar programı kullanılarak, hat sorumlusu tarafindan ilgili duruş kodu ile kayıt altına alınmaktadır. Makinenin açık zamanı içerisinde üretim, her bir pres hattı ve parça için kalıp değişimi, kalıp arıza, pres arıza, otomasyon arıza, sac bekleme, personel yokluğu vb. gibi gerçekleşmiş üretim verilerinden alınmıştır. Bu veriler Çizelge 1 ve 2'de belirtilmiştir. 
Çizelge 1: Pres Hatlarına Göre Direkt \& Endirekt Kayıplar (Arıza süresi / Açık Zaman)

\begin{tabular}{lccccccc}
\hline & & K1 & K2 & K3 & K4 & K5 & Makas Arıza \\
\hline Pres arıza & $(\%)$ & 3.0 & 0.3 & 0.75 & 0.2 & 5 & 1.25 \\
Kalıp arıza & $(\%)$ & 8.5 & 0.6 & 8 & 1.5 & 6 & - \\
Otomasyon arıza & $(\%)$ & 23 & - & - & - & 5 & - \\
Pres koruyucu bakım & $(\%)$ & 1.7 & 1.6 & 1.7 & 1.7 & 1.4 & 0.5 \\
Kalıp bakım ve hat parça adaptasyonu & $(\%)$ & 4.25 & 1.75 & 4.25 & 2.25 & 7 & - \\
Otomasyon koruyucu bakım ve parça adaptasyonu & $(\%)$ & 7 & - & - & - & 7.25 & - \\
\hline
\end{tabular}

Çizelge 2: Illk 10 Parçanın Araba Tipi-Standart Makine Birim Zamanları ve Taşıma Kabı Tanımları

\begin{tabular}{|c|c|c|c|c|c|c|c|c|c|c|c|c|c|c|c|c|c|c|c|c|c|c|c|c|}
\hline & & Tip & & p B & & p C & $\begin{array}{r}\text { Ti }_{\mathbf{I}} \\
\mathbf{D}\end{array}$ & & Taşım & a Kabı & & & & Biri & im Mz & akine & Zama & anlar & $1(\mathrm{dk} /$ & parça & & & & \\
\hline & $\begin{array}{c}\text { PARÇA } \\
\text { NO }\end{array}$ & 武 & $\begin{array}{l}\bar{\infty} \\
\simeq\end{array}$ & $\begin{array}{l}\tilde{a} \\
\simeq\end{array}$ & $\begin{array}{l}\vec{z} \\
\approx\end{array}$ & 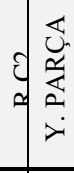 & $\begin{array}{l}\vec{D} \\
\simeq\end{array}$ & a & 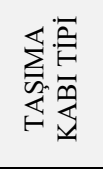 & 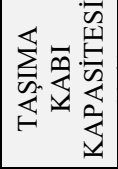 & 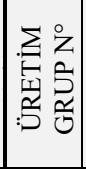 & $\begin{array}{ll} & \\
0 & 0 \\
0 & 0 \\
0 & 0 \\
0\end{array}$ & 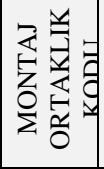 & 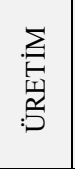 & 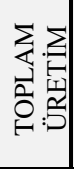 & $\stackrel{ }{=}$ & Iิ & $\stackrel{\text { m }}{2}$ & g & in & $\stackrel{8}{0}$ & 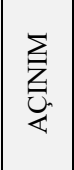 & $\begin{array}{l}\text { 荇 } \\
\frac{2}{2} \\
\dot{x}\end{array}$ & M1 \\
\hline 1 & Parça-1 & & 1 & 1 & & & & & 1700 & 300 & 101 & & 1 & 616 & 616 & 0.15 & 0.15 & 0.15 & 0.15 & 0.15 & & & & 0.12 \\
\hline 2 & Parça-2 & & 1 & 1 & & & & & 1700 & 300 & 102 & & 1 & 616 & 616 & 0.15 & 0.15 & 0.15 & 0.15 & 0.15 & & & & 0.12 \\
\hline 3 & Parça-3 & & 1 & & & & & & $\begin{array}{l}\text { ÖZL } \\
1750\end{array}$ & 110 & 103 & & 1 & 137 & 137 & 0.16 & 0.16 & 0.16 & 0.16 & & & & & \\
\hline 4 & Parça-4 & & 1 & 1 & & & & & $\begin{array}{c}\text { ÖZL } \\
1756-A \\
\end{array}$ & 71 & 104 & & 1 & 616 & 616 & 0.19 & 0.19 & 0.19 & 0.19 & & & & & \\
\hline 5 & Parça-5 & & 1 & 1 & & & & & $\begin{array}{l}\text { ÖZL } \\
1753 \\
\end{array}$ & 48 & 105 & & 1 & 616 & 616 & 0.17 & 0.17 & 0.17 & 0.17 & $\mid 0.17$ & & 0.15 & 0.17 & \\
\hline 6 & Parça-6 & & 1 & 1 & & & & & $\begin{array}{l}\text { OZL } \\
1753 \\
\end{array}$ & 48 & 106 & & 1 & 616 & 616 & 0.17 & 0.17 & 0.17 & 0.17 & 0.17 & & 0.15 & 0.17 & \\
\hline 7 & Parça-7 & & 1 & 1 & & & & & 1700 & 120 & 107 & & 1 & 616 & 616 & & 0.13 & 0.13 & \begin{tabular}{|l|} 
\\
\end{tabular} & 0.13 & 0.13 & & & \\
\hline 8 & Parça-8 & 1 & & & & & & & 620320 & 100 & 201 & & 1 & 660 & 660 & 0.17 & 0.17 & 0.17 & 0.17 & & & & & \\
\hline 9 & Parça-9 & 1 & & & & & & & 1700 & 250 & 202 & 202 & 1 & 660 & 660 & & 0.20 & 0.20 & 0.20 & 0.20 & 0.20 & & & 0.08 \\
\hline 10 & $\begin{array}{c}\text { Parça- } \\
10\end{array}$ & 1 & & & & & & & 1700 & 250 & 202 & 202 & 0 & 660 & 660 & & 0.00 & 0.00 & $|0.00|$ & 0.00 & 0.00 & & & 0.08 \\
\hline
\end{tabular}

\section{Adım 2: parça ağırlıklarının (önemleri) belirlenmesi}

Parça ağırlığı (önemleri) $\mathrm{w}_{\mathrm{i}}^{\mathrm{p}}$ ise aşă̆ıdaki denklem 1 ve denklem 2 ile elde edilmektedir.

$$
\begin{gathered}
\mathrm{k}_{\mathrm{pik}}=\sum_{\mathrm{i}=1}^{\mathrm{n}} \sum_{\mathrm{k}=1}^{\mathrm{p}} \frac{\mathrm{n}_{\mathrm{pik}}}{\mathrm{t}_{\mathrm{ik}}} \\
\mathrm{w}_{\mathrm{i}}^{\mathrm{p}}=\sum_{\mathrm{i}=1}^{\mathrm{n}} \sum_{\mathrm{k}=1}^{\mathrm{p}} \frac{\mathrm{Y}_{\mathrm{dik}} \cdot \mathrm{IS}_{\mathrm{ik}} \cdot \mathrm{t}_{\mathrm{ik}}}{\mathrm{k}_{\mathrm{pik}}}
\end{gathered}
$$

Yukarıda verilen denklem 1 ile i'nci parçanın k'nci hücredeki personel katsayısı $\mathrm{k}_{\text {pik }}$, i'nci parçanın k'nci hücredeki toplam üretim makine zamanı $t_{\mathrm{ik}}$ (saat) ve i'nci parçanın k'nci hücredeki personel sayısı $\mathrm{n}_{\text {pik }}$ kullanılarak hesaplanmaktadır. Denklem 2 ile hatlara (hücre) parça atama işleminde parça önemi (ağırlı̆̆ 1$) w_{i}^{p}$, i'nci parçanın k'nci hücredeki yüzey durumu katsayısı $Y_{\text {dik }}$, i'nci parçanın k'nci hücredeki işlem sayısı $\mathrm{IS}_{\mathrm{ik}}$, i'nci parçanın k'nci hücredeki personel katsayısı $\mathrm{k}_{\text {pik }}$ kullanılarak hesaplanmaktadır.

\section{Adım 3: Parçaların hücrelere atanması}

Üretimde analizi yapılan 163 referans parçanın, üretim hücrelerine (hatlarına) atamaları benzerlik matrisi ile Çizelge 3 'te belirlenen kriterler doğrultusunda hazırlanan Visual Basic makrosu ile yapılmıştır. Parçaların hücrelere atanması aşamasında 5 tip kısıt kullanılmıştır. 1) Pres teknik özellikleri için presleme kuvveti ( $\mathrm{kN})$ ve pres tabla boyutları 2) Kalıp teknik özellikleri için Tijli kalıp, ortak tablalı kalıp ve kalıp genişlikleri 3) Parça özellikleri için parçanın yüzey durumu ve işlem sayısı (operasyon sayısı) 4) Otomasyon özellikleri için derin çekme işlemi, tijsiz parça olma, yatay döndürme, otomasyon sistemine adapte olabilme 5) Hat yükü için hattın yüklenme oranı (Üretim hatlarında üretim çevrim periyodundan daha fazla bir yükleme yapılmaması ve kalıp, pres, otomasyon işlemleri için periyodik bakım ve adaptasyonların belirlenmesi için hat yükü ile bir sınırlandırma yapılmaktadır.)

Yukarıda açıklanan işlem adımlarına göre hesaplamalar gerçekleştirilmektedir. Kurulan modelin Visual Basic ile Excel programında oluşturulan makroların işletilmesi ile parçaların hücrelere atama işlemi sonuçları detaylı olarak çizelgeler halinde çıkarılmıştır. Çizelge 4'te örnek olarak ilk 10 parçanın hat (hücre) atamaları verilmektedir.

\section{2 Üretim Çevrim Periyodu Optimizasyonu}

Genel olarak parça çeşidinin fazla olduğu sektörlerde (otomotiv sanayi, beyaz eşya vb.) sac parça üretimleri, montaj bantlarını belli bir süre besleyecek şekilde (1, 2, 3 gün) kafile tipi 
üretim olarak gerçekleştirilmektedir. $\mathrm{Bu}$ üretim periyoduna, çevrim periyodu denir. Çevrim periyodu kavramı her işletmede,

Çizelge 3: Parçaların Hücrelere Atanmasında Teknik Kısıtlara Göre Oluşturulan Parça Atama Matrisi

\begin{tabular}{|c|c|c|c|c|c|c|c|}
\hline & & & & & Hücre $\mathbf{N}^{\circ}$ & & \\
\hline & & & K1 & $\mathbf{K} 2$ & K3 & K4 & K5 \\
\hline & & Hat (Hücre) Pres Sayısı & 6 & 6 & 6 & 4 & 5 \\
\hline & Presleme & Çift etkili pres & 450 & 450 & 500 & 500 & 1200 \\
\hline & Kapasitesi & Tek etkili pres & 320 & 320 & 400 & 400 & 800 \\
\hline CELL & Pres Tabla & Çift etkili pres & 2500 & 2500 & 2500 & 2500 & 4000 \\
\hline & Genişliği & Tek etkili pres & 2700 & 2700 & 2700 & 2700 & 4000 \\
\hline & & Kalıp genişliği kısıtı $\left(\mathrm{KG}_{\mathrm{ce}}, \mathrm{mm}\right)$ & $\leq 2500$ & $\leq 2500$ & $\leq 2500$ & $\leq 2500$ & $2200 \leq \mathrm{kg} \leq 4000$ \\
\hline KALIP TEKNIF & ZELLIKKLERİ & Kalıp genişliği kısıtı $\left(\mathrm{KG}_{\mathrm{te}}, \mathrm{mm}\right)$ & $\leq 2700$ & $\leq 2700$ & $\leq 2700$ & $\leq 2700$ & $2200 \leq \mathrm{kg} \leq 4000$ \\
\hline & & Tij kullanılan kalıplar $\quad$ (TIJ) & - & 1 & - & - & - \\
\hline & & Yüzey durum kisıtı $\quad(Y d)$ & $\mathrm{Yd}=0,75$ & $\mathrm{Yd}=0,75$ & $\mathrm{Yd}=0,75$ & $Y d>0$ & $\mathrm{Yd}>0$ \\
\hline & & İşlem sayısı kısıtı & $\mathrm{IS}=4$ & IS $>0$ & $\mathrm{IS}=5$ & $\mathrm{IS}=4$ & $\mathrm{IS}=4$ \\
\hline PARÇA ÖZ & LÍKLERİ & $\begin{array}{l}\text { Parça presleme kuvveti kısıtı } \\
\text { (Çift tesirli pres) }\left(\mathrm{F}_{\mathrm{c}} \text {, ton) }\right.\end{array}$ & $0<\mathrm{F}_{\mathrm{ge}} \leq 450$ & $\mathrm{~F}_{\mathrm{ce}} \leq 450$ & $250<\mathrm{F}_{\mathrm{ce}} \leq 500$ & $0<\mathrm{F}_{\mathrm{ge}} \leq 500$ & $\begin{array}{c}350<\mathrm{F}_{\mathrm{ce}} \leq \\
1200\end{array}$ \\
\hline & & $\begin{array}{l}\text { Parça presleme kuvveti kısıtı } \\
\text { (Tek tesirli pres) }\left(\mathrm{F}_{\mathrm{te}} \text {, ton) }\right.\end{array}$ & $\mathrm{F}_{\mathrm{te}} \leq 320$ & $\mathrm{~F}_{\mathrm{te}} \leq 320$ & $\mathrm{~F}_{\mathrm{te}} \leq 400$ & $\mathrm{~F}_{\mathrm{te}} \leq 400$ & $\begin{array}{c}250 \leq \mathrm{F}_{\mathrm{te}} \leq \\
800\end{array}$ \\
\hline & & Derin çekme işlemi kısıtı (DÇ) & 1 & - & - & - & 1 \\
\hline & & Yatay döndürme kısıt1 $\quad$ (YD) & 1 & - & - & - & 1 \\
\hline ОТОМАS & N KISITI & Oto. kolu adaptasyon kısitı (OK) & 1 & - & - & - & 1 \\
\hline OIOMAS & N КसSНI & Tij kullanılmayan kalıp (TIJ) & 1 & - & - & - & 1 \\
\hline & & Ortak tabla kalıp kısitı $\quad$ (OT) & 1 & - & - & - & 1 \\
\hline & & İkiye ayrılmayan parça $\quad$ (IA) & 1 & - & - & - & 1 \\
\hline HAT YÜI & KISITI & Hat yükü kısıtı & $\mathrm{H}_{\mathrm{y}} \leq 79$ & $\mathrm{H}_{\mathrm{y}} \leq 101$ & $\mathrm{H}_{\mathrm{y}} \leq 90$ & $\mathrm{H}_{\mathrm{y}} \leq 99$ & $\mathrm{H}_{\mathrm{y}} \leq 73$ \\
\hline
\end{tabular}

Çizelge 4: Parçaların Hatlara (Hücrelere) Atama Sonuçları

\begin{tabular}{|c|c|c|c|c|c|c|c|c|c|c|c|c|c|c|c|c|c|}
\hline & & \multicolumn{7}{|c|}{ Otomasyom Şartı } & \multicolumn{9}{|c|}{ Parça Atama Kriterleri } \\
\hline & PARÇA NO & 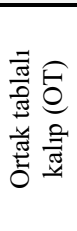 & 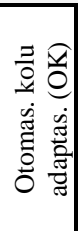 & 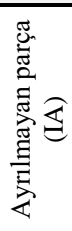 & 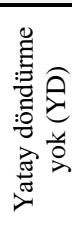 & 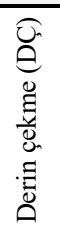 & 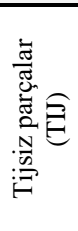 & 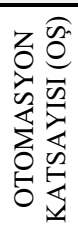 & 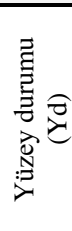 & 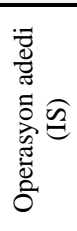 & 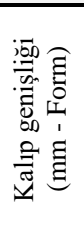 & 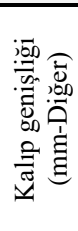 & 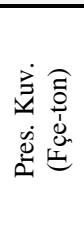 & 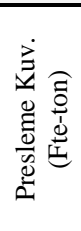 & 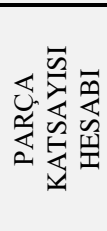 & 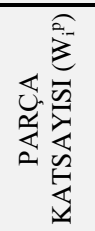 & 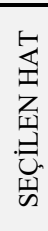 \\
\hline 1 & Parça-1 & & & 1 & 1 & 1 & & 0 & 0.5 & 5 & 2450 & 2700 & 310 & 264 & 0.29 & 0.238 & K2 \\
\hline 2 & Parça-2 & & & 1 & 1 & 1 & & 0 & 0.5 & 5 & 2450 & 2700 & 310 & 264 & 0.29 & 0.238 & $\mathrm{~K} 2$ \\
\hline 3 & Parça-3 & & & 1 & 1 & 1 & 1 & 0 & 1 & 4 & 2180 & 2700 & 305 & 259 & 0.43 & 0.358 & K4 \\
\hline 4 & Parça-4 & 1 & 1 & 1 & 1 & 1 & 1 & 1 & 1 & 4 & 2180 & 2680 & 370 & 315 & 0.57 & 0.470 & K1 \\
\hline 5 & Parça-5 & & 1 & 1 & 1 & 1 & 1 & 0 & 1 & 5 & 2180 & 2360 & 305 & 259 & 0.95 & 0.790 & K3 \\
\hline 6 & Parça-6 & & 1 & 1 & 1 & 1 & 1 & 0 & 1 & 5 & 2180 & 2360 & 305 & 259 & 0.95 & 0.790 & K3 \\
\hline 7 & Parça-7 & & & 1 & & & 1 & 0 & 0.5 & 5 & & 2500 & & 259 & 0.22 & 0.184 & $\mathrm{~K} 2$ \\
\hline 8 & Parça-8 & 1 & 1 & 1 & & 1 & 1 & 0 & 0.75 & 4 & 2170 & 2230 & 305 & 259 & 0.34 & 0.285 & K4 \\
\hline 9 & Parça-9 & & & & 1 & & & 0 & 0.5 & 5 & & 2660 & & 190 & 0.45 & 0.374 & K2 \\
\hline 10 & Parça-10 & & & & 1 & & & 0 & 0.5 & 5 & & 2660 & & 190 & 0.45 & 0.374 & K2 \\
\hline
\end{tabular}

işletmenin üretim miktarına, makine ve ekipman kapasitesine, mamul stok alanına, hammadde / yarı mamul ikmaline, üretim hazırlık sürelerine ve işletmenin hedeflerine bağlı olarak farklı şekillerde uygulanmaktadır. Üretim çevrim periyodu tespit edilirken üretim sürecinde oluşan kayıplar, üretimde oluşan kayıplar ve üretim dışı oluşan kayıplar olarak iki ana başlık altında gruplandırılmıştır. $\mathrm{Bu}$ gruplama, Renault üretim sistemlerinde kullanılan üretim performans hesaplama normu "E41.50.505.R" ile belirlenmiştir [13].

\section{Üretim Çevrim Periyoduna Etki Eden Üretim Dışı Faktörler}

Üretim çevrim periyoduna dolaylı etki eden faktörlerdir. Getirdikleri kısıtlar ile üretim periyoduna çıktısı zaman olan bir etki oluşturmaktadır. Otomobil sac parça üretiminde karşılaşılan üretim dışı faktörlerin başında hammadde ve ürün stoklama alanı ve mamulün fiziki durumu (iç yüzey ya da dış yüzey parçası olma 
durumuna bağlı olarak) taşıma kabı ebatları ve taşıma kabı sayısı gelmektedir Kafile tipi üretimde, çevrim periyoduna bağlı olarak üretilen mamul miktarı da değişkenlik gösterecektir. Dolayısıyla, çevrim süresi arttıkça mamul miktarı artacağından, stoklama alanı ihtiyacı ve taşıma kabı sayısı da artma eğiliminde olacaktır. Üretilen mamullerin ambarda stoklanması yapılırken,

Çizelge 5. Üretim Açık Zamanı Bileşenleri

\begin{tabular}{|c|c|c|c|}
\hline \multicolumn{4}{|c|}{ TOPLAM ZAMAN (Açık Zaman) } \\
\hline \multicolumn{3}{|c|}{ ÜRETIMMDE KULLANILAN ZAMAN } & ÜRETIM DIŞI ZAMANLAR \\
\hline \multirow[t]{2}{*}{$\begin{array}{l}\text { GERÇEK } \\
\text { ÜRETIM } \\
\text { ZAMANI } \\
\end{array}$} & $\begin{array}{c}\text { DİREKT } \\
\text { DURUŞLAR }\end{array}$ & $\begin{array}{l}\text { ENDİREKT } \\
\text { DURUŞLAR }\end{array}$ & ENDİREKT DURUŞLAR \\
\hline & $\begin{array}{l}\text { * Montaj } \\
\text { * Kalıp arıza } \\
\text { * Otomasyon arıza }\end{array}$ & * Enerji yokluğu & $\begin{array}{l}\text { * Planlı bakım (Kalıp) } \\
\text { * Planlı bakım (Pres) } \\
\text { * Otomasyon ekipmanları bakımı } \\
\text { * Yeni ürün devreye alma }\end{array}$ \\
\hline
\end{tabular}

mamulün tasarımına uygun taşıma kapları kullanılmaktadır. Çevrim süresine bağlı olarak, üretilen mamul miktarını karşılayacak şekilde taşıma kabına ihtiyaç vardır. Diğer bir deyişle, taşıma kabı miktarı çevrim periyodunun fonksiyonudur. Çevrim periyodu arttıkça, üretilen parça miktarı da artacağından, bu üretim miktarını karşılayacak olan taşıma kabı miktarı da artmaktadır. Bu çıkarımın tersi de doğrudur.

Hammadde temin süreleri ve hammadde parti büyüklükleri de çevrim periyoduna etki etmektedir. Hammaddenin temin süresinin uzun olduğu durumlarda, çevrim periyodunu düşürmenin işletmeye olumlu yönde büyük bir katkısı olmayacaktır. Bunun tersi olasılıkta da çevrim periyodunu kısaltarak en az maliyet ile üretim çevrim periyodu oluşturulabilir.

\section{Üretim Çevrim Periyoduna Etki Eden Üretime Bă̆lı Faktörler}

Üretim sürecinde, üretimin gerçekleştirilmesi için üretim zamanı ile hazırlık zamanları, arızalar, koruyucu bakım zamanları, çalışılmayan zamanlar gibi kayıp zamanlar oluşmaktadır. Söz konusu bu üretim zamanına direkt etki eden faktörler Çizelge 5'te gösterilmiştir. Toplam üretim zamanı (Açık zaman) üretimde kullanılan zaman ve üretim dışı zamanlar şeklinde iki ana bileşenden oluşmaktadır.

\section{Üretimde kullanılan zamanlar}

Üretimde kullanılan zamanlar, üretimin gerçekleştirilmesi için gerekli olan montaj, ayar, arızalar ve salt üretim zamanlarından oluşmaktadır. Üretim kayıtlarının sistematik bir şekilde tutulması için üretim bileşenlerine belirli kodlar verilmektedir. Üretimde kullanılan zamanların anlaşılması için bazı kavramların açıklanması gerekmektedir.

Gerçek Üretim Süresi: Makinenin, arızalar ve diğer faaliyetler dışında, sadece mamul üretiminin yapıldığı zaman dilimidir.

Direkt Duruşlar: Üretim sürecinde gerçekleştirilen montaj ve ayar çalışmaları ile üretim sürecinde oluşan arızalardan oluşmaktadır.

a) Montaj: Üretim öncesi kalıpların preslere montaj ve ayar zamanını kapsamaktadır. Uygulamada, üretim hattından sökülen kalıpların en son üretilen parçası ile bir sonraki bağlanan kalıplardan üretilen ilk parçası arasında geçen zaman dilimidir. Üretim hazırlık zamanı olarak da tanımlanmaktadır. Kalıpların preslere montajı, ayarlanması ve kalıpların sökülmesi süreleri olarak tanımlanabilir.

Çevrim süresi azaldıkça, aynı miktarda mamul üretmek için, çevrim tekrar sayısı artacağından kalıp değişim adedi de artma eğilimi gösterecektir. Dolayısıyla kalıp değişim işçiliği maliyetinin aynı oranda artış göstereceği açıktır. Bu da üretime dönüşmeyen bir işlem olduğundan, işçilik maliyetini direkt olarak arttırmaktadır.

b) Arızalar: Üretim sürecinde beklenmeyen, üretimin durmasına veya aksamasına sebebiyet veren arızalardır. $\mathrm{Bu}$ arızalar, kaynağına veya oluşum sebebine göre; Pres Arıza, Kalıp arıza, Otomasyon arıza olarak tanımlanmıştır.

Endirekt Duruşlar: Üretim sürecinde planlanmış ya da planlanmamış enerji kesintisi ve üretim için gerekli tüm unsurlar olmasına rağmen iş gören eksikliği, ya da planlı bakım ve yeni parça devreye alma çalışmaları nedeniyle üretim yapılamayan zaman dilimidir.

\section{3. Üretim Çevrim Periyodunun Matematiksel Modellemesi}

Toplam zaman (Açık zaman):

Makinenin, üretim faaliyetlerinde kullanılabileceği maksimum zaman olarak tanımlanır. Çizelge 5'de verilen Toplam açık zaman, işletme içinde yapılan hesaplamalara göre, günlük çevrim süresi, aylık, yıllık üretim süreleri esas alınarak Denklem 3 ile hesaplanmaktadır.

$$
\mathrm{T}_{\mathrm{az}}=\sum_{\mathrm{i}=1}^{\mathrm{n}} \sum_{\mathrm{j}=1}^{\mathrm{m}} \sum_{\mathrm{k}=1}^{\mathrm{p}}\left(\mathrm{T}_{\mathrm{p}}+\mathrm{T}_{\mathrm{pa}}+\mathrm{T}_{\mathrm{ka}}+\mathrm{T}_{\mathrm{oa}}+\mathrm{T}_{\mathrm{oa}}\right)+\mathrm{T}_{\mathrm{id}}+\mathrm{T}_{\mathrm{u} \mathrm{d}}
$$

$\mathrm{Bu}$ ifadede $\mathrm{T}_{\mathrm{az}}$, toplam zaman (açık zaman) olup birimi saat olarak alınmaktadır. İfadedeki diğer terimler; $T_{p}$ parça üretim süresini, $\mathrm{T}_{\text {pa }}$ pres arıza süresini, $\mathrm{T}_{\mathrm{ka}}$ kalıp arıza süresini, $\mathrm{T}_{\mathrm{oa}}$ otomasyon arıza süresini, $\mathrm{T}_{\mathrm{m}}$ kalıp montaj ve üretim hazırlık süresini, $\mathrm{T}_{\mathrm{id}}$ üretim içi endirekt kayıp süreyi, $\mathrm{T}_{\text {üd }}$ üretim dışı zamanları tanımlamaktadır.

Örneğin bir vardiya olarak 7.5 (h/gün) çalışan bir işletmede makine açık zamanı 7.5 (h/gün), 3 vardiya olarak 7.5 (h / gün) çalışan bir işletmede makine açık zamanı 3 x $7.5=22.5$ (h / gün) dür. Toplam zaman aşağıdaki gibi hesaplanır. Bir vardiyada geçen toplam süreye yemek ve dinleme molaları gibi süreler dahil 
edilmeyerek makinelerin üretime açık zamanları (Açık zaman) tespit edilmektedir ve örneğin 8 saatlik bir vardiyanın açık zamanı 7,5 saat olarak kabul edilmektedir.

Üretim planlamaları yapılırken iş gören yokluğu ve iş yokluğu nedeniyle çalışma yapılamaması söz konusu olamaz. Bu durum, üretim planlamasına dahil edilmemesine karşılık, pratikte karşılaşılabilecek bir durumdur.

\section{Parça Üretim Süresi:}

Her bir parçanın standart makine zamanları, zaman etüdü yöntemleri ile belirlenmiştir. Çevrim standart parça üretim süresi etki eden parametreler göz önüne alındığında aşağıdaki gibi modellenir:

$$
\mathrm{T}_{\mathrm{p}}=\sum_{\mathrm{i}=1}^{\mathrm{n}} \sum_{\mathrm{j}=1}^{\mathrm{m}} \sum_{\mathrm{k}=1}^{\mathrm{p}} \frac{\mathrm{M}_{\mathrm{p}} \cdot \mathrm{t}_{\mathrm{ij}} \cdot \mathrm{a}_{\mathrm{jk}}}{\mathrm{c}_{\mathrm{k}}}
$$

$\mathrm{Bu}$ ifadede $\mathrm{T}_{\mathrm{p}}$ parça üretim süresini (saat), $\mathrm{t}_{\mathrm{ij}} \mathrm{i}$ 'nci parçanın $\mathrm{j}$ 'nci makinedeki standart üretim zamanını (saat), $a_{j k}$ j'nci presin k'nci hatta atanması halinde 1, aksi halde 0 olan bir çarpanı, çk k’nci hücre (üretim hattı) makine ve/veya işçilik verimini, $M_{p}$ ise günlük parça üretim sayısını tanımlamaktadır. $T_{p}$ parça üretim süresi (saat), $\mathrm{M}_{\mathrm{p}}, \mathrm{t}_{\mathrm{ij}}, \mathrm{a}_{\mathrm{jk}}$ ve çk parametreleri kullanılarak denklem 4 ile hesaplanmaktadır

Ancak, emek yoğun çalışılan işletmelerde motivasyon, organizasyon ve eğitim faktörleri nedeniyle, standart üretim zamanlarında sapmalar meydana gelmektedir. Sapma, makine verimi anlamına gelmektedir. Kapasite ve işçilik hesaplarının gerçekçi temellere oturtulması için bu sapmaların göz önünde bulundurulması gerekir.

Makinede yapılan işçilik verimi $\eta>1$ olması durumunda, standart üretim zamanına göre yapılan üretim daha kısa zamanda gerçekleştirileceğinden, kullanılamayan makine ve iş gücü fazlası oluşacaktır.

Makinede yapılan işçilik verimi $\eta<1$ olması durumunda, standart üretim zamanına göre yapılan üretim daha uzun sürede gerçekleşeceğinden, hedeflenen miktarda üretim sağlanamayacak ve dolayısıyla kapasite yetersizliği söz konusu olacaktır. Makine verimi, üretilen her üretim kafilesi için farklı değerlerde gerçekleştirilir.

$\mathrm{Bu}$ çalışmada yapılan hesaplamalarda, üretimin uzun süreli izlenmesi sonucunda, hatlarda üretilen parçaların ortalama makine verimleri alınmıştır.

$$
M_{p}=\sum_{g=1}^{m} \sum_{i=1}^{n} \sum_{t=1}^{l} a_{g} \cdot\left(l_{i t} \cdot M_{t} \cdot k_{i t}+m_{i}\right)(\text { ad./ çev. })(5)
$$

Bu ifadede, $M_{p} g$ günlük çevrimde üretilen parça sayısını (Adet / Çevrim) cinsinden ifade etmektedir. $M_{p}$ parametresi başka bir ifadeyle, üretim planlarında bir çevrimde üretilecek parça miktarı, montaj yapılacağı günlük araba üretim miktarına (parçanın araba üzerindeki kullanım katsayısına) ve yedek parça talebine göre belirlenmektedir. Denklem 5 'te bulunan diğer değişkenlerden, $a_{g}$ g günlük çevrimi (gün), $1_{\text {it }}$ i'nci parçanın t'nci tip arabada kullanılması durumunda 1, aksi halde 0 olarak alınan bir katsayı, $\mathrm{M}_{\mathrm{t}}$ t'nci tip araba üretim sayısı (Adet / gün), $\mathrm{k}_{\mathrm{it}}$ i'nci parçanın t'nci araba tipi üzerindeki kullanım katsayısı, $m_{i}$ i’nci parçanın yedek parça sayısı (Adet / gün) olarak tanımlanmaktadır.

\section{Üretim Içi Direkt Kayıplar:}

Üretim sürecinde beklenmeyen, üretimin durmasına ya da aksamasına neden olan arızalardır. Söz konusu arızalar aşağıdaki denklemler ile ifade edilebilir.

\section{Pres ariza}

Preslerde meydana gelebilecek arıza kayılar denklem 5'te verilen ifade ile hesaplanmaktadır.

$$
\mathrm{T}_{\mathrm{pa}}=\sum_{\mathrm{i}=1}^{\mathrm{n}} \sum_{\mathrm{j}=1}^{\mathrm{m}} \sum_{\mathrm{k}=1}^{\mathrm{p}} \mathrm{T}_{\mathrm{p}} \cdot \mu_{\mathrm{pjk}} \cdot \mathrm{a}_{\mathrm{jk}}
$$

Burada, $T_{\mathrm{pa}}$ (saat) cinsinden Pres arıza süresini, $\mu_{\mathrm{pjk}}$ ise $\mathrm{j}$ 'nci presin k'ci hattaki (hücre) pres arıza oranını göstermektedir. $\mathrm{T}_{\mathrm{pa}}$ parça üretim süresi (saat / çevrim), denklem 4 vasıtasıyla $T_{p}$ (dakika / çevrim) cinsinden parça üretim süresi hesaplanarak ve $\mu_{\mathrm{pjk}}$ ile $\mathrm{a}_{\mathrm{jk}}$ parametreleri kullanılarak denklem 6 ile hesaplanmaktadır.

$$
\mathrm{T}_{\mathrm{ka}}=\sum_{\mathrm{i}=1}^{\mathrm{n}} \sum_{\mathrm{j}=1}^{\mathrm{k}} \sum_{\mathrm{k}=1}^{\mathrm{p}} \mathrm{T}_{\mathrm{p}} \cdot \mu_{\mathrm{kjk}} \cdot \mathrm{a}_{\mathrm{jk}}
$$

Burada, $T_{\mathrm{ka}}$ (saat / çevrim) cinsinden Kalıp arıza süresi, $\mu_{\mathrm{kjk}}$ ise j'nci presin k'nci hattaki (hücre) kalıp arıza oranıdır. $T_{k a}$ (saat / çevrim) cinsinden Kalıp arıza süresi, $T_{p}, \mu_{k j k}$ ve $a_{j k}$ parametreleri kullanılarak denklem 7 ile hesaplanmaktadır.

$$
\mathrm{T}_{\mathrm{oa}}=\sum_{\mathrm{i}=1}^{\mathrm{n}} \sum_{\mathrm{j}=1}^{\mathrm{m}} \sum_{\mathrm{k}=1}^{\mathrm{p}} \mathrm{T}_{\mathrm{p}} \cdot \mu_{\mathrm{ojk}} \cdot \mathrm{a}_{\mathrm{jk}} \quad \text { (saat) }
$$

\section{Otomasyon artza}

Burada, $\mathrm{T}_{\mathrm{oa}}$ (saat / çevrim) cinsinden Otomasyon arıza süresi ve $\mu_{\mathrm{ojk}} \mathrm{j}$ 'nci presin k'nci hattaki (hücre) otomasyon arıza oranıdır. $\mathrm{T}_{\mathrm{oa}}$ (saat / çevrim) cinsinden Otomasyon arıza süresi, $\mathrm{T}_{\mathrm{p}}, \mu_{\mathrm{ojk}}$ ve $\mathrm{a}_{\mathrm{jk}}$ parametreleri kullanılarak denklem 8 ile hesaplanmaktadır.

$$
\mathrm{T}_{\mathrm{m}}=\sum_{\mathrm{i}=1}^{\mathrm{n}} \sum_{\mathrm{j}=1}^{\mathrm{m}} \sum_{\mathrm{k}=1}^{\mathrm{p}} \mathrm{b}_{\mathrm{jk}} \cdot \mathrm{a}_{\mathrm{jk}} \cdot \mathrm{t}_{\mathrm{mjk}}
$$

\section{Kalıp montaj ve üretim hazırlık zamanı}

Burada, $T_{m}$ (saat) cinsinden Kalıp montaj süresini, $t_{m j k}$ (saat) cinsinden j'nci presin k'nci hattaki (hücre) kalıp montaj süresini, $\mathrm{b}_{\mathrm{jk}} \mathrm{j}$ 'nci presin $\mathrm{k}$ 'nci hatta atanması halinde 1 , aksi durumda 0 olan katsayıyı göstermektedir. $\mathrm{T}_{\mathrm{m}}$ (saat) cinsinden Kalıp montaj süresi, $b_{j k}, \quad a_{j k}$ ve $t_{m j k}$ parametreleri kullanılarak denklem 9 ile hesaplanmaktadır.

\section{Üretim İçi Endirekt Kayıplar $\left(T_{i d}\right)$}

Ortaya çıkış nedenleri, üretime bağlı olmayan enerji kesintisi vb. kayıplardır. Son 6 aylık üretim değerlerine bakıldığında, sıfıra eşit olduğundan hesaplamalarda yer almamıştır. 


\section{Üretim dışı zamanların Modellenmesi}

Üretimin bir bileşeni olmasına rağmen, direkt üretim faaliyetine dönüşmeyen, planlı bakım, yeni mamul devreye alma ve iş yokluğunu içeren zamanlardır (Çizelge 5). Planlı bakımlarda, pres ya da kalıpların periyodik bakımları, yeni mamul devreye alma zamanlarında ise kalıpların makinelere alıştırma ve deneme çalışmaları yapılmaktadır. Üretim dışı zamanlar, üretimin bir fonksiyonu değildir. Dolayısıyla, açık zaman esas alınarak hesaplanmaktadır. Üretim dışı zamanlar aşağıdaki denklem 10 ile ifade edilir.

$$
\mathrm{T}_{\mathrm{u} d}=\sum_{\mathrm{i}=1}^{\mathrm{n}} \sum_{\mathrm{j}=1}^{\mathrm{m}} \sum_{\mathrm{k}=1}^{\mathrm{p}} \mathrm{T}_{\mathrm{az}} \cdot\left(\gamma_{\mathrm{pjk}} \cdot \mathrm{a}_{\mathrm{jk}}+\gamma_{\mathrm{kjk}} \cdot \mathrm{a}_{\mathrm{jk}}+\gamma_{\mathrm{ojk}} \cdot \mathrm{a}_{\mathrm{jk}}\right)(10)
$$

Burada, $\mathrm{T}_{\text {üd }}$ (saat) cinsinden üretim dişı zamanı, $\mathrm{T}_{\mathrm{az}}$ (saat) cinsinden toplam zamanı (Açık zaman), $\gamma_{\text {pjk }}$ j'nci presin k'nci hattaki (hücre) planlı Pres bakım oranını, $\gamma_{\mathrm{kjk}}$ j'nci presin k'nci hattaki (hücre) planlı Kalıp bakım oranını, $\gamma_{\text {ojk }}$ ise j'nci presin k'nci hattaki (hücre) planlı otomasyon bakım oranını tanımlamaktadır.

\section{4. Çevrim Periyodu Maliyeti ve Optimum Çevrim Periyodunun Belirlenmesi}

$\mathrm{Bu}$ çalışmada incelenen, üretim çevrim periyodu optimizasyonunun belirlenmesinde çevrim periyoduna etki eden tüm faktörler değerlendirilmiştir. Çevrim maliyetine etki eden bu faktörler: Kalıp değişim maliyeti, taşıma kabı maliyeti, ürün stok alanı maliyeti, hammadde (sac) stok maliyeti, ayar parça ıskarta maliyeti, üretim işçilik maliyeti ve üretim hızına erişim maliyeti olarak siralanabilir.

$\mathrm{Bu}$ faktörler çevrim periyoduna bağlı olarak maliyetleri azalan ya da artan bir şekilde etkilemektedir. İşletmeler finansal olarak kâr amacı güttüğünden, tüm maliyetler ortak para biriminde değerlendirilerek optimum çevrim periyodu belirlenmiştir.

\section{Kalıp Değişim Maliyeti:}

Üretim hazırlık zamanı, bir parçanın üretiminin son parçasının tamamlanıp diğer bir parça kalıplarının bağlanarak üretimine başlanıncaya kadar geçen zaman dilimi olarak tanımlanmaktadır. Denklem 11' deki hesaplama modeli ile hesaplanmıştır.

$$
C_{m}=\sum_{i=1}^{n} \sum_{j=1}^{m} \sum_{k=1}^{p} t_{m j k} \cdot C_{p} \cdot n_{p i j} \cdot b_{i j} \cdot a_{j k} \text { (saat) }
$$

Bu ifadede; $C_{m}(\$ / y 1)$ türünden montaj işçilik maliyetini, $C_{p}(\$ /$ saat) türünden birim işçilik maliyetini, $t_{\text {mjk }}$ (saat) türünden $j$ 'nci presin k'nci hattaki kalıp montaj zamanını, $n_{\text {pij }}$ ' nci parçanın j'nci presteki işgören sayısını, $b_{j k} j$ 'nci presin k'nci hatta atanması halinde 1 aksi halde 0 olan bir katsayıyı ve $a_{j k} j$ 'nci presin k'nci hatta atanması durumunda 1 aksi halde 0 olan bir katsayı1 tanımlamaktadır. Denklem 11 ile hesaplanan montaj işçilik maliyeti, üretim çevrim periyodu modellemesinde önemli bir üretim parametresini temsil etmektedir.

\section{Taşıma Kabı Maliyeti:}

$$
\mathrm{C}_{\mathrm{t}}=\sum_{\mathrm{i}=1}^{\mathrm{n}}-\sum_{\mathrm{t}=1}^{\mathrm{w}} \frac{\left(\mathrm{M}_{\mathrm{p}}+\mathrm{M}_{\mathrm{e}}\right)}{\left(\mathrm{q}_{\mathrm{tit}} \cdot \mathrm{A}_{\mathrm{t}}\right)} \cdot \mathrm{z}_{\mathrm{it}} \cdot \mathrm{k}_{\mathrm{t}} \quad(\$ / \mathrm{yll})
$$

Burada, $\mathrm{C}_{\mathrm{t}}\left(\$\right.$ / yıl) cinsinden taşıma kabı maliyetini, $\mathrm{M}_{\mathrm{e}}$ (ad. parça / çevrim) cinsinden emniyet stoku parça miktarını, qtit (ad. parça / taşıma kabı) cinsinden i'nci parçanın t'nci tip taşıma kabına konulan parça miktarını, $z_{\text {it }}$ (\$/ ad.) cinsinden i'nci parçanın t'nci tip taşıma kabı birim maliyetini, $A_{t}$ taşıma kabı amortisman süresini $\left(5 \mathrm{y}\right.$ ıl) ve $\mathrm{k}_{\mathrm{t}}$ taşıma kabı bakım ve işletme giderleri katsayısını $(1,03)$ ifade etmektedir. Taşıma kabı maliyetini ifade eden $C_{t}(\$ / y 1)$, otomotiv şirketinin üretim yapabilmesi için gerekli yatırım miktarı denklem 12 ile belirlenmektedir.

\section{Ürün Stok Alanı Maliyeti:}

Kafile tipi üretimlerde, üretim miktarı çevrim periyoduna bağlı olarak değişmektedir. Diğer bir deyişle, ürün stok alanı, üretim çevrim periyodunun bir fonksiyonudur. Ambar taşıma kabı stok alanını $\left(\mathrm{A}_{\mathrm{ap}}\right)$ maksimum değere ulaştıran çevrim periyodunun s'nci günü net ambar taşıma kabı alanı olarak belirlenir. Brüt stok alanının bulunması için net stok alanı 1.6 katsayısı ile çarpılmış ve bina yatırımında bu değer esas alınmıştır.

$$
A_{a p}=\sum_{g=1}^{r} \sum_{i=1}^{n} \sum_{s=1}^{u} \sum_{t=1}^{w} n_{t i s} \cdot a_{i t} \quad\left(m^{2}\right)
$$

Burada, $A_{\text {ap }}\left(\mathrm{m}^{2}\right)$ cinsinden taşıma kabı stok alanını, $\mathrm{a}_{\text {it }}\left(\mathrm{m}^{2} /\right.$ grup $)$ cinsinden i'nci parçanın t'nci tip taşıma kabı için grup (birim taşıma kabı) alanını, $\mathrm{n}_{\text {tis }}$ ise i'nci parça çevrim periyodunun s'nci günündeki taşıma kabı grup adedini belirtmektedir.

$$
\mathrm{C}_{\mathrm{bt}}=\sum_{\mathrm{g}=1}^{\mathrm{r}} \frac{\mathrm{A}_{\mathrm{ap}} \cdot \mathrm{z}_{\mathrm{b}} \cdot \mathrm{k}_{\mathrm{b}}}{\mathrm{A}_{\mathrm{b}}}
$$

Burada, $\mathrm{C}_{\mathrm{bt}}(\$ / \mathrm{y}$ 1) $)$ cinsinden taşıma kabı stok alanı yatırım maliyetini, $\mathrm{A}_{\mathrm{ap}}\left(\mathrm{m}^{2}\right)$ cinsinden taşıma kabı stok alanını, $\mathrm{z}_{\mathrm{b}}\left(\$ / \mathrm{m}^{2}\right)$ cinsinden bina birim yatırım maliyetini, $A_{b}(\$ / y 1)$ cinsinden bina amortisman süresini ve $\mathrm{k}_{\mathrm{b}}$ ise bina bakım, işletme giderleri katsayısını (1.05) göstermektedir.

Ambar taşıma kabı stok alanını $\left(\mathrm{A}_{\mathrm{ap}}\right)$ maksimum değere ulaştıran çevrim periyodunun s'nci günü net ambar taşıma kabı alanı olarak belirlenir. Brüt stok alanının bulunması için net stok alanı 1.6 katsayısı ile çarpılır. Bina yatırımında bu değer esas alınır.

Ürün stok alanı $\mathrm{A}_{a p}\left(\mathrm{~m}^{2}\right)$ denklem 13 ile hesaplandıktan sonra denklem 14'te $A_{a p}$ taşıma kabı ambar stok alanı ve yukarıda verilen diğer parametreler kullanılarak taşıma kabı stok alanı yatırım maliyeti elde edilmektedir.

\section{Hammadde (Sac) Stoklama Alanı Maliyeti:}

Stoklama maliyeti, ulaşım yöntemleri, uzaklık, stoklama süresi ve maliyeti gibi faktörlere bağlı olarak değişmektedir. Otomotiv sanayinde presleme sacı olarak kullanılan saclar, büyük oranda yurtdışına bağımlı olduğundan, stoklama masrafları önem kazanmaktadır.

Çevrim ambar stok alanı: 


$$
A_{\mathrm{as}}=\sum_{\mathrm{g}=1}^{\mathrm{r}} \sum_{\mathrm{i}=1}^{\mathrm{n}} \mathrm{n}_{\mathrm{si}} \cdot \mathrm{a}_{\mathrm{is}} \quad\left(\mathrm{m}^{2}\right)
$$

Burada, $\mathrm{A}_{\text {as }}\left(\mathrm{m}^{2}\right)$ cinsinden sac ambarı net stok alanını, $\mathrm{a}_{\text {is }} \quad\left(\mathrm{m}^{2}\right)$ cinsinden i'nci parça stoklama grubu birim alanını, $n_{\text {si }}$ i'nci parça stoklama grup sayısını ifade etmektedir.

Sac stoklama alanı maliyeti:

$$
\mathrm{C}_{\mathrm{bs}}=\sum_{\mathrm{g}=1}^{\mathrm{r}} \mathrm{A}_{\mathrm{as}} \cdot \mathrm{z}_{\mathrm{b}} \cdot \mathrm{A}_{\mathrm{b}} \cdot \mathrm{k}_{\mathrm{b}}
$$

Burada, $\mathrm{C}_{\mathrm{bs}}\left(\$ / \mathrm{y}\right.$ ll) cinsinden sac stok alanı yatırım maliyetini, $\mathrm{z}_{\mathrm{b}}$ $\left(\$ / \mathrm{m}^{2}\right)$ cinsinden bina birim yatırım maliyetini, $\mathrm{A}_{\mathrm{b}}(\mathrm{y} 1 \mathrm{l})$ cinsinden bina amortisman süresini, $\mathrm{k}_{\mathrm{b}}$ ise bina bakım ve işletme giderleri katsayısını ifade etmektedir. Denklem 15 ile $\mathrm{A}_{\mathrm{as}}$ sac stoklama alanı ihtiyac1 $\left(\mathrm{m}^{2}\right)$, denklem $15^{\prime}$ te hesaplanan $\mathrm{A}_{\mathrm{as}}$ sac stok alanı değeri ve yukarıda verilen diğer parametreler denklem 16' da kullanılarak $\mathrm{C}_{\mathrm{bs}}(\$ /$ y1l) cinsinden sac stok alanı yatırım maliyeti elde edilmektedir.

\section{Ayar Parça Iskarta Maliyeti (Ayardan Attlan):}

Çevrimsel üretim yapılan sektörlerde, üretim başlangıcındaki ayar çalışmalarında zorunlu olarak ıskartaya ayrılan parça miktarı oluşmaktadır. Iskarta miktarı çevrim periyoduna bağlı olarak değişmektedir. Buradan hareketle 1skartaya ayrılan parça miktarı, çevrim periyodunun bir fonksiyonudur. Aşağıdaki hesaplama modeli ile hesaplanmaktadir.

$$
\begin{aligned}
\mathrm{C}_{\mathrm{sk}} & =\sum_{\mathrm{g}=1}^{\mathrm{r}} \sum_{\mathrm{i}=1}^{\mathrm{n}} \sum_{\mathrm{k}=1}^{\mathrm{p}} \frac{\mathrm{d}_{\mathrm{i}} \cdot \mathrm{a}_{\mathrm{pk}} \cdot \mathrm{c}_{\mathrm{si}} \cdot \mathrm{n}_{\mathrm{g}}}{\mathrm{a}_{\mathrm{g}}} \\
\mathrm{C}_{\mathrm{si}} & =\sum_{\mathrm{g}=1}^{\mathrm{r}} \sum_{\mathrm{i}=1}^{\mathrm{n}} \sum_{\mathrm{j}=1}^{\mathrm{m}} \sum_{\mathrm{k}=1}^{\mathrm{p}}
\end{aligned}
$$

Burada, $\mathrm{C}_{\mathrm{sk}}(\$ / \mathrm{y}$ ll $)$ türünden 1skarta parça maliyetini, $\mathrm{C}_{\mathrm{si}}$ (\$/yıl) sac ayar sskarta işçilik maliyetini, $\mathrm{c}_{\mathrm{p}}(\$ / \mathrm{h})$ türünden birim işçilik maliyetini, $a_{\mathrm{pk}}(\mathrm{kg} /$ parça) türünden i'nci parçanın k’nci hattaki ıskarta ağırlığını, $c_{\text {si }}(\$ / \mathrm{kg})$ türünden i'nci parça birim sac maliyetini, $n_{g}$ (gün / yıl) türünden yıllık üretim gün sayısını, $a_{p k}$ (Ad. /çevrim) türünden k’nci hat ortalama sskarta parça miktarını tanımlamaktadır. Ayar parça 1skarta maliyeti

Buradan, (\$ / yıl) türünden denklem 17 ile hesaplanan ayar parça ıskarta maliyeti $\left(\mathrm{C}_{\mathrm{sk}}\right)$ ile sac ayar sskarta işçilik maliyetini $\left(\mathrm{C}_{\mathrm{si}}\right)$ hesaplayan denklem 18 toplanarak, (\$ / y1l) cinsinden denklem 19 ile tanımlanan toplam ayar parça ıskarta maliyeti $\left(\mathrm{C}_{\mathrm{k}}\right)$ elde edilir.

$$
\mathrm{C}_{\mathrm{k}}=\mathrm{C}_{\mathrm{sk}}+\mathrm{C}_{\mathrm{si}}
$$

\section{Üretim İş̧ilik Maliyeti:}

Yapılan çalışmada standart üretim zamanlarında değişiklik olmadığından, üretim zamanları; Üretim periyodunda, işçilik zamanları değişme göstermemektedir. Denklem 20 ile hesaplanan üretim işçilik maliyeti $C_{i}$, standart makine zamanlarında ve personel sayısında değişim olduğunda bu çevrim periyodu işçilik maliyetine pozitif ya da negatif yönde yansıyacaktır.

$$
C_{i}=\sum_{g=1}^{r} \sum_{i=1}^{n} \sum_{j=1}^{m} \frac{t_{i j} \cdot n_{p i j} \cdot c_{p} \cdot M_{p} \cdot n_{g}}{a_{g}}
$$

Burada, $C_{i}(\$ / y 1)$ cinsinden toplam üretim işçilik maliyetini, $\mathrm{n}_{\mathrm{pij}}$ i'nci parçanın j'nci presteki işgören sayısını, $\mathrm{c}_{\mathrm{p}}(\$)$ cinsinden birim işçilik maliyetini, $\mathrm{M}_{\mathrm{p}}$ (ad. parça / çevrim) cinsinden " $\mathrm{g}$ " günlük çevrimde üretilen parça sayısını, $\mathrm{n}_{\mathrm{g}}$ (gün/yıl) cinsinden yıllık üretim gün sayısını, $a_{g}$ (gün) cinsinden g günlük çevrim gün sayısını ve $t_{\mathrm{ij}}$ (saat) cinsinden i'nci parçanın j'nci presteki standart üretim zamanını ifade etmektedir.

\section{Üretim Hızına Erişim Maliyeti:}

Her parçanın standart makine ve işçilik zamanları, zaman etüdü yöntemleri ile belirlenmektedir. Üretim başlangıcında, manuel hatlarda iş görenlerin üretim işlemine alışması, otomatik hatlarda ise ilk etapta yaşanan aksaklıklardan dolayı oluşan küçük kayıplar, belirlenen standart üretim zamanlarına belli bir gecikme ile ulaşılmasına neden olur. Bu süre içinde, hedeflenen üretimden daha az parça üretilerek, belli oranlarda işçilik kayıpları oluşur. Denklem 21 ile elden edilen $C_{\text {he }}$ üretim hızına erişim maliyetinde, yapılan analizlerde ilk 20 dakika içinde manuel hatlarda \%30, otomasyon hatlarında $\% 10$ ve $\% 15$ oranında bir üretim kaybı yaşandığı gözlenmiştir. Bu kayıplar üretim çevrim periyoduna bağlı olarak değişmektedir.

$\mathrm{C}_{\mathrm{he}}=\sum_{\mathrm{g}=1}^{\mathrm{r}} \sum_{\mathrm{k}=1}^{\mathrm{p}} \sum_{\mathrm{j}=1}^{\mathrm{m}} \sum_{\mathrm{i}=1}^{\mathrm{n}} \frac{(20 / 60) \cdot \lambda_{\mathrm{k}} \cdot \mathrm{n}_{\mathrm{p}} \cdot \mathrm{c}_{\mathrm{p}} \cdot \mathrm{n}_{\mathrm{g}}}{\mathrm{a}_{\mathrm{g}}}(\$ / \mathrm{yl} \mathrm{l})$

Burada, $\mathrm{C}_{\mathrm{he}}\left(\$ / \mathrm{y}\right.$ ll) cinsinden üretim hızına erişim maliyetini, $\lambda_{\mathrm{k}}$ (\%) kayıp işçilik oranını (manuel hatlar için $\lambda \mathrm{k}=0,30$, yarı otomatik hatlar $\lambda \mathrm{k}=0,15$, tam otomatik hatlar $\lambda \mathrm{k}=0,10)$.

\section{Toplam Üretim Maliyeti:}

Toplam üretim maliyeti, çevrim periyodu fonksiyonu olarak adlandırılan yukarıda belirtilen faktörler ile ilgili maliyetlerin aritmetik toplamına eşittir. Çevrim periyoduna bağlı üretim maliyetini oluşturan üretim parametreleri, çevrim periyoduna bağlı olarak artma ya da azalma eğilimi göstermektedir.

$\mathrm{C}_{\mathrm{tü}}=\sum_{\mathrm{g}=1}^{\mathrm{r}} \mathrm{C}_{\mathrm{m}}+\mathrm{C}_{\mathrm{t}}+\mathrm{C}_{\mathrm{bt}}+\mathrm{C}_{\mathrm{bs}}+\mathrm{C}_{\mathrm{k}}+\mathrm{C}_{\mathrm{i}} \mathrm{C}_{\mathrm{he}}$

Burada, $C_{t u ̈}(\$ /$ yıl) türünden g’nci çevrim gününe karşılık gelen toplam üretim maliyetini ifade etmektedir.

Üretim çevrim periyoduna etki eden faktörlerin matematiksel modellemeleri oluşturulmuştur. Oluşturulan modellemeler, Excel programında Visual Basic dilinde hazırlanan makrolar ile 1 - 30 günlük çevrim periyodunda hesaplanmış ve elde edilen veriler Çizelge 6' da sunulmuştur. Çizelge 6, mevcut ile önerilen üretim modeli, üretim çevrim periyoduna bağlı olarak, mevcut ve önerilen üretim modeli ile ilgili üretim parametreleri değişimini göstermektedir. Bu çizelgeye göre, önerilen üretim modelinde, en düşük üretim maliyetinin "6 günlük" bir çevrim periyodunda sağlanabildiği açıkça görülmektedir. Diğer bir deyişle, minimum üretim maliyetine karşılık gelen optimum üretim çevrim periyodu 6 gündür. $\mathrm{Bu}$ durumda, mevcut ve önerilen üretim modelinin üretim parametrelerinin karşılaştırması, mevcut durumda 10 gün 
olarak uygulanan çevrim periyodu ile önerilen (optimizasyon sonucu) belirlenen 6 günlük çevrim periyodu

Çizelge 6. Çalışma Öncesi ve Sonrası Toplam Çevrim Periyodu Maliyetlerinin Karşılaştırılması

Çalışma öncesi uygulanan (mevcut) üretim modelinde üretim çevrim periyodu maliyetleri $\left(10^{3} \$ /\right.$ yil $)$

\begin{tabular}{|c|c|c|c|c|c|c|c|c|}
\hline $\begin{array}{l}\text { Çevrim } \\
\text { günü }\end{array}$ & $\begin{array}{c}\text { Montaj } \\
\text { İşçiliği } \\
\left(10^{3} \text { \$ / }\right. \\
\text { YIL) }\end{array}$ & $\begin{array}{c}\text { Taşıma } \\
\text { kabı } \\
\text { yatııımı } \\
\left(10^{3} \$ /\right. \\
\text { YIL) }\end{array}$ & $\begin{array}{c}\text { Parça } \\
\text { Stok } \\
\text { Alanı } \\
\left(10^{3} \$ /\right. \\
\text { YIL })\end{array}$ & $\begin{array}{c}\text { Sac } \\
\text { Stok } \\
\text { Alanı } \\
\left(10^{3} \$ /\right. \\
\text { YIL) }\end{array}$ & $\begin{array}{c}\text { Üretim } \\
\text { İşciliği } \\
\left(10^{3} \$ /\right. \\
\text { YIL) }\end{array}$ & $\begin{array}{c}\text { Ayar } \\
\text { Iskarta } \\
\left(10^{3} \$ /\right. \\
\text { YIL) }\end{array}$ & $\begin{array}{c}\text { Üretim } \\
\text { hızına } \\
\text { erişim } \\
\left(10^{3} \$ /\right. \\
\text { YIL) }\end{array}$ & $\begin{array}{c}\text { TOPLAM } \\
\left(10^{3}\right. \\
\$ / Y I L)\end{array}$ \\
\hline 1.Gün & 802.3 & 162.9 & 57.0 & 27.8 & 641.0 & 651.4 & 174.4 & 2516.9 \\
\hline 2.Gün & 401.1 & 190.1 & 59.1 & 31.8 & 641.0 & 325.7 & 87.2 & 1736.1 \\
\hline 3.Gün & 267.4 & 232.1 & 59.3 & 37.4 & 641.0 & 217.1 & 58.1 & 1512.5 \\
\hline 4.Gün & 200.6 & 267.6 & 64.0 & 42.2 & 641.0 & 162.9 & 43.6 & 1421.7 \\
\hline 5.Gün & 160.5 & 275.8 & 65.2 & 48.0 & 641.0 & 130.3 & 34.9 & 1355.7 \\
\hline 6.Gün & 133.7 & 294.6 & 72.4 & 53.8 & 641.0 & 108.6 & 29.1 & 1333.2 \\
\hline 7.Gün & 114.6 & 323.1 & 80.3 & 58.3 & 641.0 & 93.1 & 24.9 & 1335.3 \\
\hline 8.Gün & 100.3 & 350.9 & 84.9 & 64.4 & 641.0 & 81.4 & 21.8 & 1344.7 \\
\hline 9.Gün & 89.1 & 350.9 & 92.2 & 69.2 & 641.0 & 72.4 & 19.4 & 1334.2 \\
\hline 10.Gün & 80.2 & 383.6 & 101.6 & 76.8 & 641.0 & 65.1 & 17.4 & 1365.8 \\
\hline 11.Gün & 72.9 & 416.8 & 100.2 & 81.3 & 641.0 & 59.2 & 15.9 & 1387.4 \\
\hline 12.Gün & 66.9 & 431.2 & 108.5 & 86.4 & 641.0 & 54.3 & 14.5 & 1402.7 \\
\hline 13.Gün & 61.7 & 456.7 & 111.4 & 93.8 & 641.0 & 50.1 & 13.4 & 1428.2 \\
\hline 14.Gün & 57.3 & 477.4 & 120.1 & 99.3 & 641.0 & 46.5 & 12.5 & 1454.1 \\
\hline 15.Gün & 53.5 & 511.0 & 127.9 & 105.1 & 641.0 & 43.4 & 11.6 & 1493.6 \\
\hline 16.Gün & 50.1 & 543.7 & 132.1 & 111.7 & 641.0 & 40.7 & 10.9 & 1530.3 \\
\hline 17.Gün & 47.2 & 570.6 & 139.8 & 117.8 & 641.0 & 38.3 & 10.3 & 1565.0 \\
\hline 18.Gün & 44.6 & 598.4 & 147.1 & 124.2 & 641.0 & 36.2 & 9.7 & 1601.1 \\
\hline 19.Gün & 42.2 & 633.4 & 152.3 & 129.5 & 641.0 & 34.3 & 9.2 & 1641.9 \\
\hline 20.Gün & 40.1 & 665.7 & 156.7 & 135.0 & 641.0 & 32.6 & 8.7 & 1679.8 \\
\hline 21.Gün & 38.2 & 689.7 & 154.5 & 140.1 & 641.0 & 31.0 & 8.3 & 1702.8 \\
\hline 22.Gün & 36.5 & 689.6 & 159.7 & 148.5 & 641.0 & 29.6 & 7.9 & 1712.8 \\
\hline 23.Gün & 34.9 & 726.3 & 168.5 & 154.1 & 641.0 & 28.3 & 7.6 & 1760.6 \\
\hline 24.Gün & 33.4 & 754.1 & 174.8 & 159.4 & 641.0 & 27.1 & 7.3 & 1797.1 \\
\hline 25.Gün & 32.1 & 779.8 & 179.2 & 165.7 & 641.0 & 26.1 & 7.0 & 1830.8 \\
\hline 26.Gün & 30.9 & 806.4 & 188.4 & 169.9 & 641.0 & 25.1 & 6.7 & 1868.3 \\
\hline 27.Gün & 29.7 & 851.2 & 193.2 & 175.2 & 641.0 & 24.1 & 6.5 & 1921.0 \\
\hline 28.Gün & 28.7 & 872.3 & 202.5 & 183.7 & 641.0 & 23.3 & 6.2 & 1957.6 \\
\hline 29.Gün & 27.7 & 904.1 & 207.3 & 188.7 & 641.0 & 22.5 & 6.0 & 1997.2 \\
\hline 30.Gün & 26.7 & 929.3 & 213.0 & 194.5 & 641.0 & 21.7 & 5.8 & 2032.1 \\
\hline
\end{tabular}

Çalışma sonrası uygulanan (önerilen) üretim modelinde üretim çevrim periyodu maliyetleri $\left(10^{3} \$ /\right.$ yıl $)$

\begin{tabular}{|c|c|c|c|c|c|c|c|}
\hline $\begin{array}{c}\text { Montaj } \\
\text { İşçiliği } \\
\left(10^{3} \$ /\right. \\
\text { YIL) }\end{array}$ & $\begin{array}{c}\text { Taşıma } \\
\text { kabı } \\
\text { yatırımı } \\
\left(10^{3} \$ /\right. \\
\text { YIL) }\end{array}$ & $\begin{array}{c}\text { Parça } \\
\text { Stok } \\
\text { Alanı } \\
\left(10^{3} \$ /\right. \\
\text { YIL })\end{array}$ & $\begin{array}{c}\text { Sac } \\
\text { Stok } \\
\text { Alanı } \\
\left(10^{3} \$ /\right. \\
\text { YIL })\end{array}$ & $\begin{array}{c}\text { Üretim } \\
\text { İşciliği } \\
\left(10^{3} \$ /\right. \\
\text { YIL) }\end{array}$ & $\begin{array}{c}\text { Ayar } \\
\text { Iskarta } \\
\left(10^{3} \$ /\right. \\
\text { YIL })\end{array}$ & $\begin{array}{c}\text { Üretim } \\
\text { hızına } \\
\text { erişim } \\
\left(10^{3} \$ /\right. \\
\text { YIL) }\end{array}$ & $\begin{array}{c}\text { TOPLAM } \\
\left(10^{3}\right. \\
\$ / Y I L)\end{array}$ \\
\hline 564.3 & 183.2 & 57.0 & 27.8 & 546.3 & 605.8 & 108.4 & 2092.9 \\
\hline 282.2 & 206.7 & 56.7 & 31.8 & 546.3 & 302.9 & 54.2 & 1480.8 \\
\hline 188.1 & 232.1 & 60.0 & 37.4 & 546.3 & 201.9 & 36.1 & 1302.0 \\
\hline 141.1 & 259.7 & 66.0 & 42.2 & 546.3 & 151.5 & 27.1 & 1233.8 \\
\hline 112.9 & 262.4 & 68.5 & 48.0 & 546.3 & 121.2 & 21.7 & 1180.9 \\
\hline 94.1 & 284.7 & 72.8 & 53.8 & 546.3 & 101.0 & 18.1 & 1170.7 \\
\hline \%17.2 & $\% \overline{25.8}$ & \%28.4 & $\% \overline{30.0}$ & \%14.8 & $\% 55.0$ & \%3.6 & $\overline{-}$ \\
\hline 80.6 & 321.1 & 83.1 & 58.3 & 546.3 & 86.5 & 15.5 & 1191.4 \\
\hline 70.5 & 347.7 & 87.8 & 64.4 & 546.3 & 75.7 & 13.6 & 1206.0 \\
\hline 62.7 & 347.7 & 94.9 & 69.2 & 546.3 & 67.3 & 12.0 & 1200.1 \\
\hline 56.4 & 369.3 & 99.4 & 76.8 & 546.3 & 60.6 & 10.8 & 1219.7 \\
\hline 51.3 & 398.9 & 103.0 & 81.3 & 546.3 & 55.1 & 9.9 & 1245.7 \\
\hline 47.0 & $\begin{array}{l}417.8 \\
\end{array}$ & 108.3 & 86.4 & 546.3 & 50.5 & 9.0 & 1265.4 \\
\hline 43.4 & 452.0 & 113.7 & 93.8 & 546.3 & 46.6 & 8.3 & 1304.1 \\
\hline 40.3 & 459.1 & 121.3 & 99.3 & 546.3 & 43.3 & 7.7 & 1317.3 \\
\hline 37.6 & 492.9 & 129.3 & 105.1 & 546.3 & 40.4 & 7.2 & 1358.9 \\
\hline 35.3 & 532.8 & 134.4 & 111.7 & 546.3 & 37.9 & 6.8 & 1405.2 \\
\hline 33.2 & 561.5 & 141.9 & 117.8 & 546.3 & 35.6 & 6.4 & 1442.7 \\
\hline 31.4 & 579.8 & 146.4 & 124.2 & 546.3 & 33.7 & 6.0 & 1467.7 \\
\hline 29.7 & 608.9 & 154.4 & 129.5 & 546.3 & 31.9 & 5.7 & 1506.4 \\
\hline 28.2 & 645.3 & 159.4 & 135.0 & 546.3 & 30.3 & 5.4 & 1549.9 \\
\hline 26.9 & 677.1 & 156.0 & 140.1 & 546.3 & 28.8 & 5.2 & 1580.4 \\
\hline 25.7 & 678.5 & 163.4 & 148.5 & 546.3 & 27.5 & 4.9 & 1594.8 \\
\hline 24.5 & 706.2 & 169.7 & 154.1 & 546.3 & 26.3 & 4.7 & 1631.9 \\
\hline 23.5 & 740.2 & 178.6 & 159.4 & 546.3 & 25.2 & 4.5 & 1677.7 \\
\hline 22.6 & 769.2 & 181.0 & 165.7 & 546.3 & 24.2 & 4.3 & 1713.3 \\
\hline 21.7 & 793.8 & 189.0 & 169.9 & 546.3 & 23.3 & 4.2 & 1748.2 \\
\hline 20.9 & 811.1 & 194.2 & 175.2 & 546.3 & 22.4 & 4.0 & 1774.3 \\
\hline 20.2 & 837.7 & 201.3 & 183.7 & 546.3 & 21.6 & 3.9 & 1814.7 \\
\hline 19.5 & 870.3 & 208.4 & 188.7 & 546.3 & 20.9 & 3.7 & 1857.9 \\
\hline 18.8 & 897.8 & 215.7 & 194.5 & 546.3 & 20.2 & 3.6 & 1897.0 \\
\hline
\end{tabular}

karşılaştırmasında aşağıda verilen sonuçlar elde edilmiştir. Denklem 22 ile hesaplanan üretim parametreleri toplam maliyetlerinin, üretim çevrim periyoduna bağlı olarak değişimi, farklı değerlerde olduğu çizelge 6'dan anlaşılmaktadır. 1 ile 30 gün arasındaki çevrim periyotlarına karşılık gelen toplam üretim maliyetleri denklem 22 ile elde edilerek çizelge 6'da ve aynı zamanda şekil 4'te grafik şeklinde sunulmuştur.

\section{Araştırma Sonuçları ve Tartışma}

Çevrim optimizasyonuna etki eden faktörlerin 1 ile 30 arası hesaplamaları çizelge $6^{\prime} \mathrm{da}$ verilmiştir. Bu hesaplamaya göre şekil 4' de görülen grafik elde edilmiştir. Deney sonuçlarından elde edilen Şekil 4'te verilen bu eğriler sayısal olarak analiz modeller, tüm maliyetler için ayrı ayrı ve toplam maliyeti verecek şekilde Çizelge 7'de verilmiştir

Toplam çevrim periyodu maliyetinin en düşük olduğu çevrim periyodunu almak için Denklem 23'de gösterildiği gibi fonksiyonun türevini alarak ve sıfıra eşitlenerek elde edilen 3. Mertebeden polinomun köklerinden biri minimum çevrim sayısını vermektedir. Böylece minimum Toplam çevrim periyodu maliyetini veren çevrim gün değeri elde edilmiş olur.

$$
\frac{d C_{t \ddot{u}}}{d x}=0
$$

Buradan minimum maliyetli çevrim periyodu 6 gün olarak elde edilmektedir.

Çizelge 8'de mevcut üretim durumunda uygulanmakta olan 10 günlük mevcut çevrim periyodu ile, önerilen (optimize edilen) 
çevrim periyodu modellemesi ile belirlenen hücrelere parça ataması sonucu hesaplanan 6 günlük çevrim periyoduna göre artan veya azalan faktörleri göstermektedir. $\mathrm{Bu}$ tabloya göre montaj ve işçilik maliyeti, ayar parça iskarta maliyeti, üretim hızına erişim maliyetlerinin arttığı ancak diğer parametrelerin azaldığ 1 görülmektedir. Toplamda ise \%14.29'luk bir kazancın elde edildiği görülmektedir. Başka bir ifadeyle, çevrim periyodu

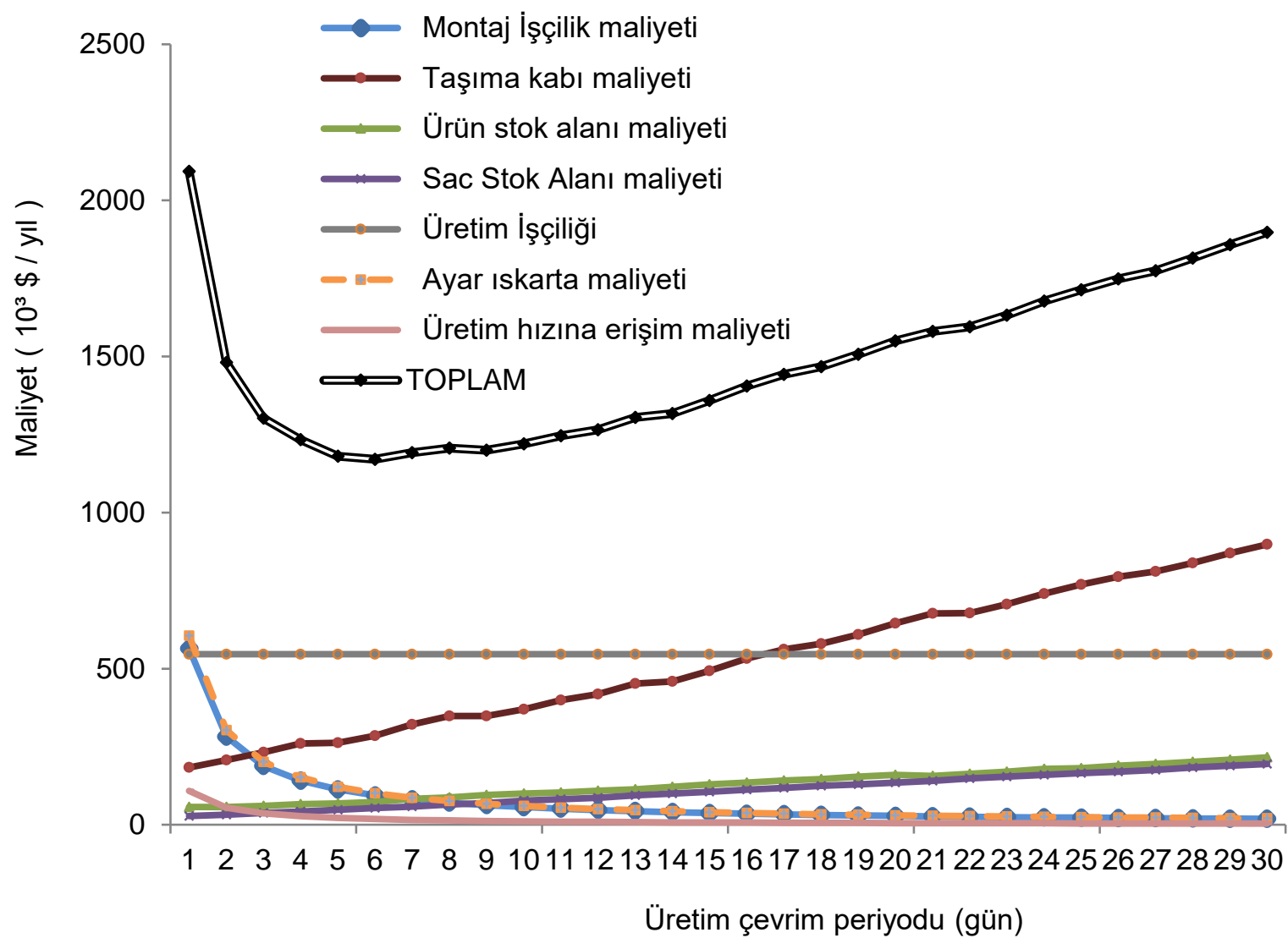

Şekil 4. Çalışma Sonrasına (Önerilen Üretim Çevrim Periyoduna) Göre Toplam Üretim Maliyet Grafiği (10³ \$ /yıl)

\begin{tabular}{|c|c|c|c|}
\hline $\begin{array}{l}\text { Çizelge 7. Üretim Çevrim } \\
\text { Periyodu Matematiksel Modelleri } \\
\quad \text { Maliyet }\end{array}$ & Sembol & Eğrinin fonksiyonu & Hata $\left(\mathbf{R}^{2}\right)$ \\
\hline Kalıp montaj maliyeti & $\mathrm{C}_{\mathrm{m}}$ & $y=7 x^{3}+71 x^{2}-376 x+858$ & 0.9800 \\
\hline Taşıma kabı maliyeti & $\mathrm{C}_{\mathrm{t}}$ & $y=24.82 x+140.17$ & 0.9964 \\
\hline Ürün stok alanı maliyeti & $\mathrm{C}_{\mathrm{bt}}$ & $y=5.61 x+43.64$ & 0.9966 \\
\hline Hammadde (sac) stok maliyeti & $\mathrm{C}_{\mathrm{bs}}$ & $y=5.84 x+18.55$ & 0.9994 \\
\hline Ayar parça 1skarta maliyeti & $\mathrm{C}_{\mathrm{k}}$ & $y=0.01 x^{5}+0.33 x^{4}-6.64 x^{3}+70.82 x^{2}-376.47 x+857.88$ & 0.9800 \\
\hline Üretim işçilik maliyeti & $\mathrm{C}_{\mathrm{i}}$ & $\mathrm{y}=546.30$ & 1.0000 \\
\hline Üretim hızına erişim maliyeti & $\mathrm{C}_{\mathrm{he}}$ & $y=108.43 x^{-1}$ & 1.0000 \\
\hline Toplam çevrim periyodu maliyeti & $\mathrm{C}_{\mathrm{tü}}$ & $y=0.72 x^{4}-14.57 x^{3}+1553 x^{2}-7949 x+2.67$ & 0.9800 \\
\hline
\end{tabular}




\begin{tabular}{|l|c|c|r|}
\hline $\begin{array}{l}\text { Çevrim periyoduna etki eden } \\
\text { faktörlerin değişimi }\end{array}$ & Sembol & $(\boldsymbol{\%})$ & \\
\hline Montaj işçilik maliyeti & $\mathrm{C}_{\mathrm{m}}$ & 17.23 & $\nearrow$ \\
\hline Taşıma kabı yatırım maliyeti & $\mathrm{C}_{\mathrm{t}}$ & -25.78 & \\
\hline Parça stok alanı yatırım maliyeti & $\mathrm{C}_{\mathrm{bt}}$ & -28.37 & $\searrow$ \\
\hline Sac stok alanı yatırım maliyeti & $\mathrm{C}_{\mathrm{bs}}$ & -29.97 & \\
\hline Üretim işçilik maliyeti & $\mathrm{C}_{\mathrm{k}}$ & -14.77 & $\searrow$ \\
\hline Ayar parça ıskarta maliyeti & $\mathrm{C}_{\mathrm{i}}$ & 55.00 & $\nearrow$ \\
\hline Üretim hızına erişim maliyeti & $\mathrm{C}_{\mathrm{he}}$ & 3.60 & $\nearrow$ \\
\hline \multicolumn{2}{|c|}{ TOPLAM } & & $\mathbf{- 1 4 . 2 9}$
\end{tabular}

Bu çalışmada, Hücresel Üretim Sistemi yaklaşımı ile Pres hattı yükleme ve üretim çevrim periyodu optimizasyonu incelenmiştir. Geliştirilen modelin uygulandığı bir makro kodlama gerçekleştirilmiştir. Yazılan makro program vasıtasıyla, Oyak Renault Otomobil Fabrikaları A.Ş. Pres Atölyesinde halihazırda uygulanan üretim modeli ile önerilen model için birbirinden bağımsız olarak hesaplama yapılmış ve sonuçlar karşılaştırılmıştır. Kurulan modelde, Atölyenin imal ettiği tüm parçalar için pres hattı yükleme problemi incelenmiştir. Dolayısıyla, çalışma konusunu oluşturan çevrim periyodu

- CÇalışmada elde edilen iş yükü dağılımına göre, mevcut üretim modelinde pres hatlarının dengesiz bir iş yükü dağılımı söz konusu iken, önerilen üretim modeli ile daha dengeli bir iş yükü dağılımı elde edilmiştir.

- Çalışmada geliştirilen üretim modeli ile iş yükünde otomasyon hatlarında artış, manuel hatlarda ise düşme görülmüştür. Bunun anlamı, işçilik maliyetinin ve buna bağlı diğer maliyet girdilerinin azalması şeklinde özetlenebilir.

- İkinci aşamada, program ile üretim çevrim periyodu optimizasyonu, mevcut ve önerilen üretim modellerinin her ikisi için de yapılmıştır. Önerilen üretim modelinde, en düşük üretim maliyetinin "6 günlük” bir çevrim periyodunda sağlanabildiği görülmüştür.

- Montaj işçilik maliyetlerinde 10 günlük çevrim periyoduna göre daha fazla montaj yapıldığından \%17 artış, 10 günlük çevrim periyoduna göre montaj sayısındaki artışa bağlı ayar parça ıskarta maliyetinde $\% 55$ artış, üretim hızına erişim maliyetinde $\% 3,6$ artış elde edilmiştir. Buna karşılık, taşıma kabı yatırımlarında " $\% 25,78$ ", parça stok alanı yatırım maliyetinde “-\%28,37” ve sac stok alanı yatırım maliyetinde “-\%29,97”, üretim işçiliğinde “\%14,77” kazanç sağlanmıştır.

- Çevrim periyodu optimizasyonu çalışması ile toplam “\%14,29" oranında bir tasarruf (kazanç) sağlanmıştır. Diğer bir deyişle, çevrim periyodu optimizasyonu ile 195100 (\$/yıl) kazanç sağlandığı görülmüştür.

- Yıllık bazda sağlanan bu kazanç, ürün maliyetini azaltıcı yönde rol oynayıp, işletmenin rekabet gücünün arttırılmasında önemli bir yere sahip olacaktır.

- Üretim parametreleri maliyetlerinin, üretim çevrim periyoduna bağlı olarak değişimi farklı değerlerde olmaktadır. modellemesinde, program girdileri, parça sayısı, parça referans sayıs1 (163 adet) gerçek değerler üzerinden birebir olarak alınmıştır. Bunun sonucunda, bilgisayar program çıktıları, gerçek üretim parametrelerini yansıtmaktadır.

Önerilen model ile ilgili bilgisayar programı, hesaplamayı iki aşamada gerçekleştirmiştir. Birinci aşamada, Pres Atölyesinde üretilen 163 referans parçanın, benzerlik kriterlerine göre Pres

Çizelge 8. Uygulanan 10 Günlük Çevrim Periyoduna Göre Önerilen Durumda (Optimizasyon Sonucu) Belirlenen 6 Günlük Çevrim Periyodunda Artan ya da Azalan Maliyetlerin Karşılaştırılması

hatlarına (5 hat) otomatik olarak ataması gerçekleştirilmektedir. Hesaplanan sonuçlar çizelge $7^{`}$ de verilmiştir.

Yapılan çalışmadan elde edilen sonuçlar aşağıda maddeler halinde sunulmuştur:

- Çalışma öncesinde yordamsal olarak belirlenen çevrim periyodu, çalışma sonrasında çevrim periyodu maliyetinin minimum olmasına karşılık gelen Üretim Çevrim Periyodu 6 gün olarak hesaplanmıştır.

- Diğer taraftan, kalıp montaj sürelerinin ve ayar 1skarta adetlerinin düşürülmesi, üretim hızına erişim kayıpları gibi üretime bağlı faktörlerde yapılacak olan Kaizen çalışmaları ile çevrim periyodu maliyetleri önemli oranda düşürülebilir. Gelecekte böyle bir çalışma konusu önerilebilir.

- Model, kriterler değiştirilerek kullanılabilecek esnek bir yapıya sahiptir. Bu çalışmada önerilen model, değişebilen günlük araba üretim miktarlarına göre hesap yapabilme yeteneğine sahiptir. Günlük araba üretim miktarı değiştiğinde, doğal olarak iş yükünün pres hatlarına dağılımı ve üretim çevrim periyodu değişiklik gösterebilecektir. Ancak üretim çevrim periyodu, üretim maliyetini daima en küçükleyen bir parametre olacaktır. Tasarlanan model, günlük araba üretim miktarı ne olursa olsun, iş yükünün pres hatlarına optimum olarak dağılımı ve minimum üretim maliyeti temin eden üretim çevrim periyodunu hesaplayabilecek bir yapıya sahiptir. Dolayısıyla, önerilen model, sabit bir araba üretim miktarı için hesaplama yapabileceği gibi, değişken araba üretim miktarları için de hesaplama yapabilecek kapasitededir.

- Çalışmada incelenen modelin, yeni inşa edilecek veya halihazırda üretim faaliyeti gerçekleştiren pres veya diğer üretim atölyelerinde optimum hat yüklemesi, üretim hatlarının iş yükü dağılımı ve üretim maliyeti optimizasyonunda kullanılarak pratik sonuçlar vereceği görülmektedir.

- Kalıp montaj maliyeti çevrim periyoduna etki eden en önemli faktörlerdendir.

- Ürünlerin stok alanına taşınması ve stoklanması amacıyla kullanılan taşıma kapları maliyeti çevrim periyoduna göre doğrusal olarak maliyetlere etki ettiği görülmüştür.

- Yığın imalat yapılan üretimlerde, parçaların stoklanması amacıyla stok alanlarının oluşturulması zorunludur. Stok alanları çevrim periyoduna bağlı olarak doğrusal olarak artmaktadır. 
- Benzer şekilde, çevrim periyodunda ihtiyaç duyulan sac miktarının stoklanması amacıyla sac stok alanlarına ihtiyaç duyulmaktadır. $\mathrm{Bu}$ stok alanları, çevrim periyodunun artışı ile çevrim periyodu maliyetini lineer olarak etkilediği görülmüştür.

- Kalıp montajından sonra, prosesin üretim parametrelerine göre ayarlanması için ayar yapılması gerekmektedir. Bu süreçte üretilen parçalar ıskartaya ayrılmaktadır. Iskarta olan parçalar nedeniyle hammadde ve işçilik kayıpları oluşmaktadır. Iskarta

- Her parçanın üretime girdikten sonra ilk 20 dakika içerisinde manuel hatlarda iş görenin parçaya adaptasyonu ve otomatik hatlarda küçük duruşlar nedeniyle bir kayıp oluşmaktadır. Bu kayıplar maliyeti regresyon analizinde $\mathrm{y}=108.43 \mathrm{x}-1$ şeklinde bir fonksiyon oluşturmaktadır.

- Toplam çevrim periyodu maliyeti çevrim periyoduna etki eden faktörlerin aritmetik toplamı olarak bulunmuş ve çevrim periyoduna göre değişimi gösterilmiştir.

\section{Teșekkür}

$\mathrm{Bu}$ çalışmada verdiği destekten dolayı Oyak Renault Otomobil Fabrikaları Anonim Şirketine teşekkür ederim.

\section{Kaynakça}

[1] A. R. Yelles-Chaouche, E. Gurevsky, N. Brahimi, and A. Dolgui, Reconfigurable Manufacturing Systems from an Optimisation Perspective: A Focused Review of Literature, Int. J. Prod. Res. 0, 1 (2020).

[2] C. H. Glock and E. H. Grosse, The Impact of Controllable Production Rates on the Performance of Inventory Systems: A Systematic Review of the Literature, Eur. J. Oper. Res. 288, 703 (2020).

[3] F. E. K. Sato and T. Nakata, Energy Consumption Analysis for Vehicle Production through a Material Flow Approach, Energies 13, (2020).

[4] H. Rasay and A. M. Golmohammadi, Modeling and Analyzing Incremental Quantity Discounts in Transportation Costs for a Joint Economic Lot Sizing Problem, Iran. J. Manag. Stud. 13, 23 (2020).

[5] M. Kitazawa, S. Takahashi, T. B. Takahashi, A. Yoshikawa, and T. Terano, Improving a Cellular Manufacturing System through Real Time-Simulation and-Measurement, Proc. - Int. Comput. Softw. Appl. Conf. 2, 117 (2016).

[6] K. V. Durga Rajesh, M. Mani Krishna, M. A. Ali, and P. V. Chalapathi, A Modified Hybrid Similarity Coefficient Based Method for Solving the Cell Formation Problem in Cellular Manufacturing System, Mater. Today Proc. 4, 1469 (2017).

[7] B. A. Norman and K. L. Needy, International Journal of Worker Assignment in Cellular Manufacturing Considering Technical and Human Skills, 37 (2010).

[8] Ö. F. Yılmaz, Sanal Hücresel Üretim Sistemi İçin Üretim Kontrol Sisteminin Belirlenmesi, Gazi Üniversitesi Fen Bilim. Derg. Part C Tasarım ve Teknol. 6, 644 (2018).

[9] Ö. F. Yılmaz, E. Çevikcan, and M. B. Durmuşoglu, Scheduling Batches in Multi Hybrid Cell Manufacturing System Considering Worker Resources: A Case Study from Pipeline Industry, Adv. Prod. Eng. Manag. 11, 192 (2016).

e-ISSN: 2148-2683 parça miktarına bağlı maliyetler incelenmiştir. Çevrim periyodunun ayar parça 1skarta maliyetini üstel bir fonksiyon şeklinde etkilediği görülmüştür.

- Üretim işçilik maliyetlerinin çevrim periyodunda değişiklik göstermediği görülmüştür. Bu nedenle regresyon analizinde elde edilen doğrusal fonksiyondur.

[10] Y. Can, A Modelling About the Optimisation of the Production Cycle Period and the Stamp Line Loading with the Approach of the Cell Production System, Osmangazi University, 1999.

[11] R. G. Askin, Contributions to the Design and Analysis of Cellular Manufacturing Systems, Int. J. Prod. Res. 51, 6778 (2013).

[12]R.G. Askin and S. Estrada, Investigation of Cellular Manufacturing Practices, in Handbook of Cellular Manufacturing Systems (2007), pp. 25-34.

[13]T. Géniteau, Temps d'état et indicateurs de suivi des performances des moyens de production, Ingénierie Maintenance et Performance des Moyens, E41.50.505.R /H, (2009). 